\title{
The Hungarian Táltos and the Shamanism of Pagan Hungarians. Questions and Hypotheses
}

\author{
Éva Pócs \\ "East-West" ERC Research Group, Institute of Ethnology, RCH, \\ Hungarian Academy of Sciences, Budapest
}

\begin{abstract}
One of the purposes of this study is to outline the research problem related to the wizard called táltos and a hypothesized shamanism in the pagan, pre-Christian religion of the Hungarians. Another purpose is to present the results of new research on this issue. The first part of the study is the analysis of the activities of a weather wizard called táltos from the $16^{\text {th }}$ to the $21^{\text {st }}$ century, as well as its related beliefs and narrative motifs. Then I present the process in the course of which researchers of the pre-Christian pagan "ancient religion" - Gyula Sebestyén, Géza Róheim, Sándor Solymossy, Vilmos Diószegi and others - created the fictitious construct of the táltos and reconstructed the Conquest-era shaman in line with the model compiled from the attributes of shamanism of various periods and various peoples. The criticism of Vilmos Diószegi's construct of the táltos is followed by the introduction of new research results. Their main points: modern táltos beliefs and narratives show many correlations with Balkan - especially Bulgarian - folk beliefs and folk epics. The táltos and táltos-epics show the closest correlation with the beliefs of Bulgarian dragon-men who were fathered by a dragon or eagle and born with wings or other animal traits, as well as with the adventures of heroes of epic songs who slay the dragons of the underworld and are protected by the spirit of the eagle, dragon, rooster, crane, etc. We also need to consider the influences of Slavic storm wizard practices and the werewolf beliefs and narratives of the Balkans. The influences of Balkan peoples on Hungarian culture are indubitable, partly the result of the Bulgaro-Turkic relations between the 5th and 9th centuries and partly the consequences of Slavic relations after the Conquest. It is likely that at the time of the Hungarian Conquest, there was a weather magic practice similar to those of the Balkan dragon-men, as well as a weather wizard called táltos. However, the construct of the research tradition represented by Diószegi must be refuted: there is no evidence of a shaman-táltos similar to the "classic" Eurasian shaman who was initiated in the world tree and established contact with the spirit world through a ritual performance, in a drum-induced ecstasy.
\end{abstract}

Keywords: táltos, weather wizard, dragon man, folk beliefs, pre-Christian religion, shamanism, heroic epic, Balkans, Turkic shamanism 
My primary goal in this paper ${ }^{1}$ is to outline the research problem surrounding the figure of the wizard called táltos and the hypothesized shamanism of the "ancient Hungarian religion". In Hungarian research - as well as in this paper - the term "ancient religion" refers to the pre-Christian, "pagan" religion of Hungarians. Based on archaeological and linguistic data, researchers think - or would like to think - that some remnants of this religion still existed at the time of the "Conquest", that is, at the time when more than a thousand years ago Hungarian tribes coming from the East settled in the Carpathian Basin. ${ }^{2}$ My secondary goal is to outline my new research results about the BulgaroTurkic relations concerning this research problem.

I first started researching táltos beliefs in the 1980s, when I wrote several studies on the European correlations of the táltos; later I wrote a book about the specialists of supernatural communication found in witch trial documents, including the táltos (Pócs 1988, 1989a, 1989b, 1995, 1996, 1997), in the spirit of a hypothesized "European" shamanism. ${ }^{3}$ In recent years, my work on the systems of supernatural communication in Central Southeastern Europe has once again turned my attention to the issue of the Hungarian táltos and Conquest-era shamanism. An overview of the enormous database of modern Hungarian folk beliefs and the exploration of the new documents of early modern source materials led to the emergence of new issues.

\section{THE NOTION OF THE TÁLTOS IN HUNGARIAN SCHOLARSHIP}

Shamanism had had an important role in the lives of both Uralic and Altaic peoples, ${ }^{4}$ thus the gradual exploration of the linguistic and historical past of the Hungarians led to the search for its traces in the "pagan" religion of the Hungarians. These ambitions were related to European Romantic ideology, done in the spirit of the search for a national identity, and thus research was also somewhat symbolically and ideologically charged, serving to

\footnotetext{
${ }^{1}$ The research resulting in these findings was funded by The European Research Council as part of the seventh term of the European Community (2007-2013) based on Research Agreement ERC 324214. For the sake of uniformity, every name and title in Cyrillic has been transcribed according to the Croatian Latin spelling, except for the names of Russian, Ukrainian or Bulgarian authors of English publications in the list of references, the names and works of whom are transcribed according to English spelling.

${ }^{2}$ See for example: PAIS 1975a-d; Fodor 2003, 2004.

${ }^{3}$ In his first book on the benandanti of Friuli (Ginzburg 1966) and later in his 1989 book (GinzBuRG 2003 [1989]), Carlo Ginzburg hypothesized about a pre-Christian European "shamanistic substratum" based on the "shamanistic" wizards and their European parallels he found in $18^{\text {th }}$-century wizard trials. I myself accepted Ginzburg's findings and supported it with additional Hungarian and Balkan data (see, e.g., Pócs 1994, 1995, 1996). As for what I, too, assumed, was an "ancient European shamanism," and regarding some of its aspects, I accept both Vilmos Voigt's verbal and István Pál Demény’s written criticism (DemÉny 2000). I can refute most of Demény’s critical comments regarding specific táltos data, but this is not the place for it.

${ }^{4}$ In this study, following the Hungarian scholars of shamanism, I use the concept of shamanism in the narrower interpretation of László Vajda, in which he suggests that only the "shamanism" complex of Siberian/North-Central Asian peoples should be tentatively considered shamanism. The characteristic features of this are: an otherworldly journey in ecstasy; the drum's important role in inducing ecstasy; battling in many shapes, with specific motivations; illness and symbolic death as initiation (Vajda 1959). Vajda's definition does not mention it, but in my opinion, it is important to take into consideration the public, ritual performance character of shamanism, and, more broadly, its role in the community.
} 
fulfill a sense of identity. The pursuit of proving that the religion of the Hungarians had a distinctive character which set it apart from European religions was implicit in such research. This is also one of the reasons why numerous scholars argue to this day that the pre-Christian religion of the Hungarians was shamanism, or that shamanism was at least in some form part of their religion, ${ }^{5}$ thus, a somewhat nostalgic, illusory construct of shamanism and the táltos was created from more than just actual elements, and even preeminent scholars participated in its creation, knowingly or unknowingly.

The táltos was chosen for the role of the pagan Hungarian shaman, who initially appeared in the works of researchers of the ancient religion as a priest presenting sacrifices. ${ }^{6}$ Arnold Ipolyi invested the figure of the hypothesized sacrificial priest with contemporary beliefs about the táltos: born with teeth, táltos children dying at the age of seven, notions of battle, the practice of seeing buried treasure, and even the folktale motif of the táltos horse. Nonetheless, he did not yet associate the figure and activity of the táltos with the concept of shamanism. ${ }^{7}$ Ferenc Kállay in 1861 and Antal Csengery in 1884 already mentioned the shamanic drum of Turkic peoples, relating it to the pagan Hungarian táltos ${ }^{8}$ the drum, however, gained a key role in Gyula Sebestyén's magic drum article of 1900, thereby opening a new era in research. ${ }^{9}$ This study was the starting point of a deluge of conceptualizations continuing to this day, according to which the wizard called táltos was a key figure in Hungarian folk beliefs and non-Christian religious practice, similar to that of the Eurasian shaman among Finno-Ugric and Altaic peoples: a preserver of the oriental vestiges of the ancient religion. ${ }^{10}$ Sebestyén already considered the táltos-shaman correlation as evidence, as did the 1917 article by Lajos Kálmány, which presented data of táltos duels on the Southern Great Plain (KÁLMÁNY 1917). In his 1925 book, in a chapter summarizing the hypothesized characteristics of the táltos, Róheim laid the foundation for the construction of the ideal image of the Eurasian shaman, compiled from the characteristic features of the shamanism of various Ural-Altaic linguistic relatives. ${ }^{11} \mathrm{He}$ outlined the figure of the táltos of the ancient religion in light of this ideological model of the shaman, basing it on the features of the contemporary táltos and data from two $18^{\text {th }}$-century táltos trials, while also using Sebestyén's "táltos drum" data and Eurasian parallels. Róheim considered the Hungarian táltos the remnant of a Finno-Ugric-based Turkic shamanism, and he believed that this was closest to the shamanism of the Yakuts. He determined that the battle of animal spirits in the shape of bulls or stallions was the most important common motif. The most important táltos features, in his view, are trance, battle, being born with teeth, táltos and

\footnotetext{
${ }^{5}$ See István Fodor's overview and the indexes he references: FodOR 2003:343-344.

${ }^{6}$ See IPOLYI 1854:447-452; for the details on János Horváth's 1817, Ferenc Kállay's 1861, and Antal Csengery's 1884 publications, see: Diószegi 1971b:54-57, 87-96, 265-294.

${ }^{7}$ IPOLYI 1854:234-237, 447-452.

${ }^{8}$ Diószegi 1971b:87-96; 291.

9 SEBESTYÉN 1900.

${ }^{10}$ See for example: SEBestyén 1900; RóHeim 1925:7-40, 1984 [1961]; SOLYMossy 1929, 1937; DiószeGi 1952, 1953, 1958 a, 1958b, 1960, 1967, 1969, 1973; Hoppál 1975, 1981, 1984, 1988, 1996, 1998; DöмÖтöR T. 1982, 1983; Pócs 1994 and those mentioned in Note 1; DemÉNY 1994, 1999a, 1999b, 2000. For a comprehensive evaluation of the ancient religion, see VoIGT 1997-1998.

${ }^{11}$ Such elements include: Buryat shaman's drum, Chukchi initiation, Yakut and Sami battles, Teleutian shaman's cap, Khanty diviners, and so on (RóHeIM 1925:8-20).
} 
horse relationship, healing by conjuring spirits, and the táltos-witch antagonism, and possibly the owl as a helping spirit. Róheim continued to use elements - non-real and foreign to the táltos, presented in Sebestyén's magic drum article - as evidence, and even supplemented Sebestyén's drum data with a nursery rhyme mentioning sieve and drum together and the linguistic forms of the sieve=horse identification; these data are still present in the study of the ancient religion as relics referring to the drum of the ethnic Hungarian shaman (RóHeIm 1925:7-40).

Among the scholars of folk nrarratives, Sándor Solymossy was the first to contribute to the further development of the research fiction of the táltos, though he initially only sought the oriental parallels or elements in our folktales (Solymossy 1922, 1929, 1930, 1931). In the spirit of the reconstruction of the táltos, a sub-chapter presenting the "UralAltaic belief systems" and centered around the description of the shamanism of several related peoples found its way into his chapter on Ancient Mythology of the Hungarians in Ethnography of the Hungarian People, in which he incorporated the features of the táltos already known from Róheim (Solymossy 1937:352-367).

\section{VILMOS DIÓSZEGI'S CONSTRUCT OF THE HUNGARIAN SHAMAN}

Vilmos Diószegi adopted the idea of the táltos as an ancient Hungarian shaman from his predecessors and lined up a massive amount of evidence ${ }^{12}$ to confirm and elaborate the image of the táltos formulated by Róheim, even building a "shamanistic worldview" around the figure of the táltos. In his two books summarizing the reconstruction of Conquest-era Hungarian shamanism (Diószegi 1958a, 1967), and using "genetic ethnic characteristics" as the guiding principle of his methodology, ${ }^{13}$ he supplemented Róheim's series of data with further motifs relating to cosmogony and shamanic initiation. As a conclusion of his overview of the attributes and activities of the táltos published in two books and several studies, ${ }^{14}$ he, in line with Róheim's view, thought that the Hungarian táltos retained the characteristics of a Finno-Ugric-based Turkic shamanism and was its westernmost representative and regarded the $20^{\text {th }}$-century narrative motifs of the táltos as relics of a shamanism that still existed in the Conquest era. He also reconstructed the ancient as well as the Conquest-era táltos in light of the model, as an ideal image, compiled from the well-known attributes of the shamanism of several Eurasian peoples, adopted from Róheim. After declaring in his 1967 book that "as a result of a multifaceted inquiry, a whole series of our religious beliefs can be traced back to the time of the Conquest," he set out the Conquest-era worldview of the Hungarians and the elements of its backbone, shamanism, and the attributes of the táltos as he reconstructed them,

\footnotetext{
${ }^{12} \mathrm{He}$ used the data of folk collections that proliferated in the meantime, the answers to Question 190 in the Hungarian Ethnographic Atlas ("child born with teeth") and his own collections specifically focused on the táltos.

${ }^{13}$ This principle is repeatedly voiced in his 1958 book; for a detailed explanation of his methodology, see DiószeGi 1954.

${ }^{14}$ Works partially or fully summarizing his research results: Diószegi 1952, 1953, 1958, 1960, 1967. Brief overviews for the rest of the world: Diószegi 1958b, 1971a. Overviews of two of his books: 1958a:435-436, 1967:134-135.
} 
in four main points: 1. "shamanic worldview" and soul concepts; 2. birth, calling, initiation; 3. drum; 4. trance, “conjuring spirits”, and battle (DiósZEGI 1967:134-135).

Through his comprehensive work and explicit desire to create a canon, Diószegi gained enormous prestige among scholars, and the vast majority of his contemporaries and later researchers accepted his conclusions. Thus, Diószegi's main theses served as the basis for Tekla Dömötör's and Mihály Hoppál's writings about the táltos and the ancient religion. ${ }^{15}$ Mihály Hoppál, later Pál István Demény, and most recently Ferenc Pozsony supplemented the reconstruction with some further data. ${ }^{16}$

In terms of oral narratives, János Berze Nagy, following in the footsteps of Solymossy, sought the vestiges of the ancient religion primarily in the body of folktales, but he muddled the picture by over-dimensioning Solymossy's views and drawing illogical parallels (Berze NagY 1958). Ágnes Kovács, also working along the SolymossyDiószegi line, compiled a body of "shamanistic" folktales about the Tree that Reached up to the Sky in line with the notion of the world tree of the Hungarian shaman (Kovícs 1984). Of the archeologists that focused on the Conquest era and based their research on Diószegi's results, Károly Mesterházy, István Dienes, and István Fodor's comprehensive work contributed to the mapping of Conquest-era shamanism by deciphering newlyfound archaeological relics, and by raising new questions about the social background of Conquest-era shamanism, the communal role of the táltos, and the worldview that is reflected in artefacts. ${ }^{17}$

Gyula László was the first to hit a critical tone regarding Diószegi's work (with regard to false generalizations, the chronological problems of transmission, and the interpretation of archaeological finds) (LÁszLó 1959). In a later paper, he offered a more exhaustive critique of Diószegi's hypotheses: he questioned the etymology of the word táltos, the motif of "dismemberment" during the initiation of the táltos, and he averred that the táltos had no connection to the Tree that Reached up to the Sky and he had no drum or "shamanic attire". He only considered the battle, being born with teeth, and the predestination of a táltos as true attributes of a táltos. His sharpest criticism was directed at Diószegi's construct of the Conquest-era táltos from heterogeneous "memory nuggets" of different origins: he declared that "the Siberian shaman cannot be used" to conceptualize the former Hungarian táltos (LÁszLó 1990). (My ideas explicated below are in line with László's criticism on several points.) While accepting the basic principles, a short while later István Pál Demény also voiced his doubts regarding the motifs of the shamanic drum or the world tree, for example (DEMÉNY 2000).

\footnotetext{
${ }^{15}$ See their work mentioned in Note 10.

${ }^{16}$ Hoppál supplemented the reconstruction of the shamanic drum with Manchu data: the shaman uses a drum to cross the water, by which he was trying to prove the sieve-shamanic drum connection based on the Hungarian motif of the wizard floating in a sieve. He also tried to explain the textual motif of a milk-drinking táltos with the antitoxic effects of milk, assuming that the Hungarian shaman used the milk to counteract the effects of the fly agaric (Amanita muscaria) used in North Eurasia as a vision-inducing narcotic (Hoppál 1992:159-164). Demény investigated the eastern parallels of the táltos battle, following it all the way to China (DemÉNy 1999a); Pozsony assumed "shamanistic" traces in the masked, musical rites of the Moldavian hejgetés and urálás taking place on New Year's Eve (Pozsony 2005).

${ }^{17}$ Mesterházy 1978, 1994; Dienes 1975 (he associated the trepanned skulls of Conquest-era tombs with mental illnesses); FODOR 2003, 2004.
} 
Some of our scholars of oral narratives and folk music have studied the "shamanistic" motifs found in Hungarian folktales through other, not exactly shaman-centric approaches. Lajos Vargyas should be mentioned foremost: he did not connect the phenomena of the Tree that Reached up to the Sky, the táltos horse, or a táltos battle and underworld dragon battle with hypothesized Conquest-era shamanic rituals, but considered them rather as narrative motifs of various epic genres (folktale, heroic epic); he predominantly found the parallels between the phenomena not in shamanistic practice but in epics with "shamanistic" motifs (VARGYAS 1977, 1978, 1985, 1988). Pál István Demény had similar observations regarding the issues of Conquest-era epic poetry (DEMÉNY 1996:162-163, 1997, 2000:156-157, 2002:209-210). Vilmos Voigt, in his studies providing a synoptic view of the research of the ancient religion (VOIGT 1997-1998, 1998), expressed some criticism of Diószegi's basic concept, and he also considered the motifs of the dragon battle, the Tree that Reached up to the Sky, and the táltos battle as components of Conquest-era epics of Turkic origins. By 2012, he no longer considered a significant part of Diószegi's hypotheses substantiated (VorGT 2012).

Before continuing to the more detailed discussion of the research problems related to the táltos and to presenting my own new results, I will briefly introduce the táltos in light of directly relevant data in my database that has significantly expanded since Diószegi's work.

\section{THE TÁLTOS IN HUNGARIAN FOLK BELIEFS}

Folklore collections from the $19^{\text {th }}$ through the $21^{\text {st }}$ century have furnished us with a very rich material of táltos narratives, which allow us to draw some conclusions about certain elements of the practice that may have been around even at the end of the $20^{\text {th }}$ century. A great majority of $20^{\text {th }}$ - and $21^{\text {st }}$-century narratives are about weather wizards and, to a lesser extent, about treasure-seeing táltos. In the $20^{\text {th }}$ and $21^{\text {st }}$ centuries, remembrances of specialists called táltos who performed community tasks were only prevalent in the easternmost groups of Hungarians living in Romania, in Szekler Land, Gyimes (Ghimeş) and Moldavia; however, those few táltos who are remembered in these regions were diviners and none of the motifs of the weather wizard narratives were associated with them. In Szekler Land, Gyimes and Moldavia, there is a vivid memory of practicing weather wizards, but neither their terminology ("weather-adjuster", "guardian of fields", "guardian of ice", "ice-bearer", etc.) nor their divergent practices are related to the táltos. There were some táltos on the Great Plain that were still practicing now and then as treasure-seers in the middle of the last century. (A well-known example is Pista Pénzásó of Tiszafüred, who, with a somewhat disturbed mind, was obsessively looking for buried money; in the villages of the region, he was considered a táltos, but he was not known to possess any other táltos attributes.)

A different picture is painted by the táltos documents of $17^{\text {th }}$ - and $18^{\text {th }}$-century witch trials, which have now expanded to 35 as a result of discoveries of new sources. ${ }^{18} \mathrm{In}$ these sources, the táltos emerge as specialists who are versatile, capable of performing "occult" tasks appropriate for the given historical and social situation: they cure, divine,

\footnotetext{
${ }^{18}$ In a recent study, I presented these thirty-five táltos in detail (Pócs 2017).
} 
see treasure, are sometimes accused of bewitchment and witchcraft, and often identify other witches and cure bewitchment. All these roles could be played simultaneously by a single person. Weather magic was less commonly among their tasks, and it never seemed to be their exclusive function; of the thirty-five táltos references in the trial documents, only three or four may indicate a person classified as a weather wizard. In any case, this is an interesting contradiction with the high volume of data about táltos battling for the weather found in $20^{\text {th }}$-century legends. ${ }^{19}$

Hence, there is a contradiction between the practical function of the táltos of the trials and $20^{\text {th }}$-century tradition. We cannot know for sure whether there were generally few weather wizards practicing in Hungarian peasant communities, or if they were just less often accused of witchcraft; after all, weather wizards in the service of the entire local community were less likely to be in the cross-hairs of witchcraft accusations induced by personal conflicts within the community. Another important difference is that every táltos in the witch trial documents that stood accused of weather magic or communication with the otherworld through a trance was a woman, in contrast to the "dueling" táltos men of $20^{\text {th }}$-century táltos legends. I believe that, in this respect, this is primarily about the duality of narrative tradition vs. actual practice. I suspect that $20^{\text {th }}$-century táltos narratives are primarily representatives of an old epic tradition and not direct reflections of actual táltos rituals. This epic tradition, as I shall later discuss in more detail, is fundamentally rooted in the (Conquest-era?) epics whose táltos heroes are naturally male.

If we go back in time even further, the data essentially disappear, at least as far as the role and activity of the táltos are concerned. Thanks to documentation by Dezső Pais, we have records of $13^{\text {th }}$ - through $18^{\text {th }}$-century personal names of Táltos, as well as some references in $15^{\text {th }}$ - and $16^{\text {th }}$-century codices that refer to various specialists of magic, and a táltos duel is mentioned in a $17^{\text {th }}$-century source related to a boundary lawsuit. ${ }^{20} \mathrm{As}$ for the Conquest era, however, we have no sources that refer to the existence of táltos practicing as magico-religious specialists; aside from the incidental indirect evidence of archaeological and linguistic relics, all conclusions relating to this era had to be deduced from later documents, especially from $20^{\text {th }}$-century narratives.

Due to the aforementioned differences regarding temporal dimensions, in the following I shall summarize the characteristics of the modern táltos emerging from our documents in two steps, going backward in time. Starting with $19^{\text {th }}$ - through $21^{\text {st }}$-century folklore data, I group the data around a distinctive set of motifs. These narrative motifs may only incidentally describe certain types of táltos; certain sets of motifs are only loosely associated, and essentially every motif could be related to any other. Thus, we can only tentatively speak of táltos types like the windy/tempestuous táltos, the werewolf táltos that transforms into animals, or the "dragon" táltos who was born with wings.

\footnotetext{
${ }^{19}$ For a synthesis: DiósZEGI 1958:342-395, 1973:189-204; Pócs 2012a:442-452. In this paper, I cannot present the abundant illustrative material for each characteristic motif, only examples of a very small number of the most typical features.

${ }^{20}$ Doctors, diviners, dream readers: PAIS $1975 \mathrm{c}: 85$; references to the $17^{\text {th }}$-century data: RóHEIM 1925:16-17.
} 
These categories, which are distinct merely on the narrative level, hardly reflect the reality that is only vaguely perceptible behind the narrative tradition. ${ }^{21}$

\section{"Windy" and "tempestuous" táltos: tempestuous and windy attributes, double being characteristics}

A very large proportion of narratives portray the táltos as a weather wizard, a halfhuman, half-spirit double being with the attributes of tempest and wind. ${ }^{22}$ Along with being human, there is a permanent presence of a demonic nature in him which during communication becomes one with the otherworldly storm demons. Sometimes he resides on earth as a human, other times as a spirit in the world of storm clouds, and the diffuse boundary between the world of humans and demons is easily permeable to him.

A particular form of supernatural communication typical of double beings emerges most markedly in accounts of the activities of weather wizards: when the táltos become spirit beings, their human form "disappears" in the descending fog or thunderstorm, which can even be noticed by outside observers. Through their spirit attributes, cloud or fog make them invisible, "carry them off", "lift" them up, making them disappear, they themselves becoming fog or clouds: "The tátos was in the cloud-wind. I heard he took someone up there" ${ }^{23}$ or: "The tátos went into the clouds. A great big cloud came and had taken him". ${ }^{24}$ "... He barely took two steps, a fog descended behind him. Such that we could no longer see him. And he disappeared" ${ }^{25}$ The storm táltos turns into a storm demon to battle hostile demons that bring gale and hail, and he returns from the storm clouds wet or marked by lightning. On the southern Great Plain, the táltos was called tátorjános ("tempestuous", "windy"), which also refers to his turbulent nature.

The intensive folklore collecting of forty to fifty years ago revealed that narratives of storm táltos, usually associated with weather magic, were prevalent mostly in the central regions of the Hungarian language area. In the western, southern and northern regions of Hungary, the figure of the garabonciás has often been associated with similar beliefs. Nevertheless, the "stormy" attributes appeared in all types of táltos, forming a basic layer of táltos beliefs across the Hungarian language area.

\footnotetext{
${ }^{21}$ The most complete collection of published and unpublished Hungarian data which provided the basis for this study: Táltos, Garabonciás, Birth groups of the Hungarian Folk Belief Archive. Collection of texts and typologies selected from the archive material, covering all important motifs: Pócs 2012a. Due to space limitations, I had to forego specific references to all the data used - I only name the primary sources for the data cited.

${ }^{22}$ A vast array of this kind of dual beings are known in European belief systems, including the werewolf (wolf-man), the mora/Mahr/mara/nightmare creatures, fairies and witches, or the Romanian strigoi. They usually have human and demonic/animal, "living" and "dead" variants. Data on the South Slavic, Eastern Slavic and Hungarian dual beings, for example: HerTz 1862:123, KLAPPER 1910; Tolstoj-Tolstaja 1981; Burkhart 1989:71-94; PóCs 2002, 2014.

${ }^{23}$ Padé/Padej, Serbia (formerly Torontál County), Ferenczi 1974:263.

${ }^{24}$ Mohol/Mol, Serbia (formerly Bács-Bodrog County), Ferenczi 1974:263.

${ }^{25}$ Blackwater/Crna Bara, Serbia (formerly Torontál County), FerEnCZi 1974:269.
} 


\section{The "werewolf" táltos: peculiarities of birth, origins, birthmarks, calling, initiation}

A large number of data from $20^{\text {th }}$-century collections, mostly from the central part of the language area, is related to the extraordinary birth of the táltos (being born with teeth or some other mark, two rows of teeth, six fingers, with a caul, or with a bristle or hair on his back). These marks are usually guarantees of supernatural abilities, indicating that the táltos is not a common man but a double being belonging to both the human and supernatural world. As they said in Mezőtúr of a táltos who was born with a caul: "Because he always said that he was not of this world. He was partly from here, partly from the otherworld". ${ }^{26}$

Some of the peculiarities of birth are related to certain animal (werewolf) characteristics: ${ }^{27}$ some táltos traditions indicate that they are double beings capable of transforming into animals, who are at home in both the cultured world and in nature, and whose destiny is predetermined at birth, or even in utero, a cyclical alternation of stages of life and death awaiting them (at the age of seven, and every seven years afterward, the "werewolf" táltos child must disappear; he is gone, disappears forever, dies, then returns; he must periodically do battle to determine the next cycle, etc.). ${ }^{28}$ The metaphors of the táltos being "carried off", "taken", "forced to leave" can in some cases be interpreted as spirit táltos or animal spirits summoning or carrying off the táltos into their world, where he is initiated: "If these tátos were able to carry off the one born with teeth, then it also became like them, a tátos. (...) the child born with teeth would be raised for seven years; I do not know where these are raised...."29

According to some of our data it is a horse, according to other data it is an eagle, a "big black bird" or a dragon that carries off the táltos "forever"; or it takes him as a helping/ calling spirit "to do battle". For example, according to a data from Gyula (Tolna County), a child born with teeth "would be taken by a dragon at the age of seven. They would ascend to the clouds in the shape of a dragon serpent (...) and tear up the [storm cloud]." ${ }^{30}$

All these attributes can be classified as general Central Eastern European werewolf characteristics that go far beyond the data of the táltos. Being born with teeth, animal transformation, and battling in the shape of an animal against hostile wizards could also be the attributes of rural specialists called cunning folk or wise folk (healers), but beliefs about being born with teeth may also relate to ordinary children with werewolf characteristics. Being born with two rows of teeth is usually an attribute of Eastern European double beings whose living and dead forms - i.e., their living human shape and demonic counterpart - exist simultaneously (werewolf, vampire, strigoi, mora, witch). These shapeshifter traits, intertwined with tempestuous/windy properties and storm magic, are one of the dominant layers of táltos beliefs.

\footnotetext{
${ }^{26}$ Jász-Nagykun-Szolnok County, collection of Éva Pócs, 1962.

27 The narrower meaning of the word werewolf is 'man-wolf'; in a broader sense, it is also used to denote 'animal-man', i.e., shapeshifter (the werewolf is the most common version of European shapeshifters, but there is also bear-man, serpent-man, dog-man, etc.).

${ }^{28}$ See these werewolf features in detail: Pócs 2002.

${ }^{29}$ Kistelek, Csongrád County, collection of Vilmos Diószegi, 1954.

${ }^{30}$ Collection of Bertalan Andrásfalvy, 1961.
} 
Those born with wings and dragon features

Intertwined with the "tempestuous" and shapeshifter motifs but also separate from them due to certain distinctive features that are only characteristic of them is the tradition of men possessing bird, serpent, or dragon features who were born with small wings or feathers (sometimes specifically eagle or crane) in their armpit, so that they could fly away from their mother even as infants. If their wings are not cut, they may wear them hidden under their clothing when they are older, or they may at a certain age grow wings, become eagles or dragons, and fly away: "They are born in the morning, and with wings. They walk as well as fly. Only they are invisible, they fly so that they cannot be seen. (...) When the táltos child grew up and grew wings, around age twelve to fourteen, he left to do battle." ${ }^{31}$

Included in this category are some mentions of táltos that transform into fish, serpent, or rooster, or appear in the shape of a chicken or beings that can transform into winged creatures capable of flight: dragons, eagles, cranes. Perhaps the motifs relating to the animal father, progenitor, ancestor or parent of the táltos (eagle, crane, bull, wolf, dog, etc.) found in southern Great Plain and southern Transylvanian data could be included here, as well as the motifs of extraordinary abilities manifesting in childhood (an infant that talks or develops rapidly, a very strong little boy).

Often coinciding with data of those born with wings or feathers but geographically much more widespread are the scant and scattered data about serpent, dragon, or, less commonly, bird spirits (owl, eagle, rooster, crane, horse) used for helping with divination. The same goes for traditions of animal ancestors: they may coincide with the data of those born with wings and feathers, but they are often independent of them. Besides the táltos and other similar wizards, birthmarks and their associated traditions of animal fathers and helping spirits are usually part of the childhood of heroes and powerful people and may appear in heroic epics and historical legends as well. We would like to point out that these data will become more readily understandable when placed in the framework of Bulgarian and Serbian wizard beliefs and epics.

\section{The battles}

The richest material in táltos motifs is about the battles; these narratives can roughly be divided into three large groups corresponding to the previously mentioned three groups.

There is a wide variety of stories about the battles of the storm táltos; if they include information about the manner of the battle, they usually portray the táltos as battling in a human form, alone or more often as part of a team, against storm demons, hostile táltos, or "bad" dragons that bring hail: "In the cloud - because táltos go into the clouds - they say the táltos are kicking, that's why it's lightning. In the cloud, when those big thunderstorms happen, it's those tátos going at each other, to see who is stronger. They are tearing the clouds apart. The strongest power is with the tátos..." 32

\footnotetext{
${ }^{31}$ Both quotes: Sárrétudvari, Hajdú-Bihar County, collection of Ilona P. Madar, 1963.

${ }^{32}$ Nagybátony, Heves County, collection of Vilmos Diószegi, 1956.
} 
The notions of these battles include several stereotypical mythical motifs, the most common being the motif of a wandering táltos asking for milk, being rejected, and causing a thunderstorm. Storm táltos appear as masters of storm clouds and storm demons, but they are not necessarily engaged with the demonic world just through direct communication. They have other means of controlling thunderstorms, such as "cutting" the cords of the "tied up" clouds with an axe, or banishing the demons with sticks, or prayers, or incantations, etc.

The most common narratives, predominant on the Great Plain, are about werewolf táltos that transform into animals, who must do battle in the shape of an animal with the hostile táltos of another settlement or region. The battle usually takes place between animals (bull, less often horse, dragon, still less often boar, wolf, dog) of a contrasting color, white and black or white and red, or possibly in the form of red and blue flames. The goal is usually to avert a thunderstorm or hail, and (re)turn it to the enemy, and less often to bring about rainfall. Battles for the weather are often accompanied by meteorological events, wind storms, thunderstorms, the same as with other weather wizards and battle types.

Part of the battle motifs have a certain learning/initiation nature: the táltos must fight a hostile táltos to become a practicing weather wizard. Numerous data, mainly from southern Transdanubia, refer to a duel- or bout-like battle with an "ordinary" animal in a naked, human form. For example:

\footnotetext{
"The bull was just roaming the streets, it was bound to attack men. (...) When the Gypsies came, they tried scaring the bull, but it charged them, and this strong Gypsy, (...) he dropped his bass, lunged at the bull. With one hand he grabbed hold of one of its horns, with the other its nostril, and spun the bull so that it bellowed in pain. He spun the bull until he just slammed it against the ground, and the people just watched in amazement. Then the news spread that Old Bogdán was a táltos and had battled with a bull. Bogdán Pali was his name. His descendants were also that strong." ${ }^{33}$
}

This kind of battle, along with other werewolf traits, signals a kind of "werewolf wizard" and the narrative types associated with it, but this tradition seems to be unrelated to practicing táltos. It is primarily an epic tradition with many stereotypical mythical motifs (for example, the táltos announcing in advance that he needs to do battle, calling for a helper, etc.), and highly interwoven with werewolf beliefs (animal alter ego, born with teeth or animal traits, the cyclical nature of battles, etc.).

Narratives of the battles of dragon/winged táltos include further characteristic motifs in addition to the werewolf and storm magic features. The táltos heading out to battle is taken by a dragon, serpent or eagle into the cloud, or he travels on the back of a dragon or serpent. He himself may take the shape of a similar flying creature, or he may battle in the storm cloud in his human form but has a dragon or eagle helper or guide in this spirit battle. Similar roles can be fulfilled by rooster, chicken, serpent or horse helpers. Each of these may grow a wing and turn into a dragon or eagle in the otherworldly dimension.

The data relating to the birthmarks and battle methods of a "winged táltos" do not denote a coherent weather wizard táltos, although they are apparently clustered around

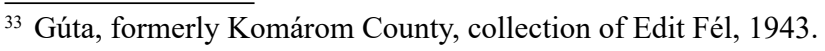


such a being. Data about a táltos battling in the shape of a dragon are more widespread than about a táltos born as an eagle/dragon: it is only the dragon's shape that battle narratives associate with the dragon as a helping "spirit animal". A common component of dragon táltos narratives is the mythical motif of a táltos requesting milk for his serpent helper/himself in order to grow wings/turn into a dragon/gain the ability to fly.

We do not know to what degree these data can be "originally" linked to the rather evanescent figure of a táltos born with wings; for the time being, we can only deduce a practicing wizard in light of the Balkan parallels discussed below. This much can be stated, however: data of winged/dragon táltos are clustered in a geographically distinct south-southeast region, in Csongrád, Bihar and Békés counties, but they can be found in Borsod county and Southern Transylvania as well. Based on the $17^{\text {th }}-18^{\text {th }}$-century witch trials, there were at least two people - one táltos woman in Jászberény and one in Debrecen - that were dragon táltos.

All in all, we are dealing with various types of battles, which may be indicative of different táltos roles in the past; however, we cannot infer this from the modern narratives. What may have been the significance of battle in the hypothesized ritual activity of the táltos in the past? Was it really a "soul journey" during trance, as the majority of researchers of Hungarian ancient religion assumed? There are no data from the modern age about táltos battles in trance, apart from one or two texts that may be interpreted in this way and one narrative of a dream battle. (In Moldavia and Szekler Land, a couple of data of weather wizards that are not called táltos refer to communication with storm demons during a trance, but not to a battle. ${ }^{34}$ ) When we evaluate the battle motifs, we must think of their almost universal nature: the "otherworldly" spirit battle, in very different contexts and in various animal forms, is a general phenomenon; wizards, seers, demonic "night witches" carry on such battles all across Europe! ${ }^{35}$ (Part of the battles mentioned in the táltos trials are actually the night battles of táltos in the role of witches or antiwitches carried on at home, in a family environment, in dreams and visions.) We can only distinguish the táltos battle through a combination of other features (animal forms, the nature of otherworlds). But these features are merely a part of textual traditions. The narratives usually portray the battle as taking place in the earthly environment or in a storm cloud but as being a real, physical adventure (with certain miraculous transformation motifs from folk epics). What we can know for sure, in light of current data about such battles, is the presence of these epic motifs in the past in the intellectual culture of Hungarians.

Returning to the animal helpers in battles, we have to say a few words about the táltos horse. Apart from the widespread folktale motif of the helping horse, the horse does not appear as a helper in the $20^{\text {th }}$-century data of "real" táltos battles. The táltos horse as advisor to renowned historical figures (primarily St. László) with whom the heroes leap from mountain peak to mountain peak and cover long distances at lightning-fast speeds has also nothing to do with a táltos practicing weather magic. ${ }^{36}$ Still, the details of two táltos trials, as we will see below, link the helping táltos horse with the battling táltos,

\footnotetext{
${ }^{34}$ See in detail: Pócs 2019: Weather Wizards chapter.

${ }^{35}$ See, for example, the night battles of witches: Pócs 2010.

${ }^{36}$ See, for example, the táltos horse of Gyimes: Zoltán Magyar 1998. (Cf. "One jump to the Calvary, and nine to Királyhágó...”, János Arany: Szent László.)
} 
and there are some mythical references to a táltos "looking for his horse". Nonetheless, I believe that in the case of the táltos horse and any animal helpers or animal alter egos of the táltos communicating with the otherworld, we are dealing with traditions that are unrelated and running on separate tracks.

The extent to which the above-presented attributes were components of the beliefs and legends surrounding practicing táltos and the extent to which this narrative tradition was part of their táltos identity can, of course, not be established today. The whole táltos battle tradition is textual in nature and lacks the subjective dream or vision experience. If we seek signs of true supernatural communication, credible witness accounts of trance states, or first-person narratives of táltos about their otherworldly experiences, only the $17^{\text {th }}-18^{\text {th }}$-century witch trials provide some details. ${ }^{37}$

\section{The táltos in witch trials}

In our $17^{\text {th }}$ - and $18^{\text {th }}$-century trial records, several táltos are presented as important community functionaries of rural and small-town communities, in some cases even providing a detailed picture of their various activities. Of the above-mentioned traits considered to be táltos attributes, these sources make several mentions of the táltos being born with teeth and being divinely predestined in utero for the táltos life, but there are also two data concerning dragon helpers, one of which is found in the testimony of a táltos woman from Jászberény who confesses to practicing weather magic. Then there is data on "turning into an eagle", but this turns out to be only a verbal charm that was recorded in a 1741 witch trial in Paks and is almost certainly merely a narrative motif..$^{38}$

The táltos battle is discussed in the trial records in four cases. The trial of the táltos Zsuzsanna Kömüves, Judit Szöcs and György Tapodi took place in 1740 in front of the Council of Miskolc (BodGál 1960:308-311). ${ }^{39}$ György Tapodi confirms during his interrogation that when the time comes, the táltos must go into a heavenly battle, and on a regular basis, namely, at Pentecost and on St. John's Day. This trial record documents the entering of a trance state by Judit Szöcs: she practices the ritual trance-inducing method of hydromancy, through which she changes into a fish (the same record reports on the transformation of the táltos into pidgeons and foxes, too): "At dawn on the third day of Pentecost, she went to the courtyard and took a bowl in her hand and gazed into it; her neighbor saw this and asked her: 'What are you looking at?' To which the girl replied: 'Nothing at all.' After a short while, she shook herself, turned into a fish, and disappeared for three days" (BoDGáL 1960:196).

Transforming into a fish is theoretically a motif of "winged" táltos, but this does not fit with another statement by the same girl: "the girls fight separately, and the men also fight separately" (BODGÁL 1960:309). This coincides with $20^{\text {th }}$-century data of group battles of weather wizards. In another case, in the record of a trial taking place between 1730 and

\footnotetext{
${ }^{37}$ In my book on the táltos in witch trials, I wrote in detail about some of these táltos (Pócs 1999, Chapter 7); in a recent study, I presented all these táltos in detail: 2016.

${ }^{38}$ The trial of Ilona Vörös in 1741: SCHRAm 1970:485.

${ }^{39}$ For more detail on the trial: Pócs 2016:254-255.
} 
1736, ${ }^{40}$ Ilona Borsi, a healer practicing in Bihar, Szatmár, and Bereg counties, confesses that troops of táltos gather on Örhegy three times a year (at Pentecost, and in the months of St. Michael and St. James - September and July, respectively). Three other táltos confess about battles in the "sky". One of them is battling "evil" to avert hail, and the other two "for the realm" or against the "German táltos". The latter two are especially unlikely to be reporting on their own trance experience but rather incorporating commonly known narrative motifs into their confessions. Although the true ritual practice of some of the táltos may have been still in place, it seems that even in the $18^{\text {th }}$ century, the táltos battle was a narrative stereotype rather than an actual community task of the táltos. According to our data, at least on the Great Plain (as it was in the $21^{\text {st }}$ century), narratives of táltos battles were widely known at the time, but the actual community activity of the weather táltos was already waning. Ilona Borsi, mentioned above, refers to a battle between two beings when talking about a childhood (perhaps "initiatory") vision in which a male and female táltos battle in the "sky" as bulls but who are at the same time wrestling in human form, naked (LEHOCZKY 1887:305). The little girl had to watch this in order to learn. At the very least, this information demonstrates knowledge of the narrative motifs of two táltos wrestling while naked and doing battle in the shape of a bull.

In both trials quoted here, the notion of the horse as an animal helper appears, which may be related to táltos who actually practiced their vocation. As a little girl, Ilona Borsi is being transported by the táltos "training" her to the scene of her vision on flying horses, and they even try to give her a horse, "trying to see whether she herself could ride a táltos horse", but this was an unsuccessful attempt. The little girl is encouraged by the horses of the táltos not to be afraid of the sight of the battling táltos. ${ }^{41}$ In this unique scene, the possibility of interpreting the táltos horse both as the horse alter ego and the helping spirit of its master is simultaneously present. The trial record of the above-mentioned hydromancer Judit Szöcs of Miskolc also notes that she is "looking for a horse to ride" (BoDGÁL 1960:311). In the case of Judit Szöcs and her companions, there is also talk of some sort of rivalry, a test of strength taking place among the táltos, which the táltos involved in the case describes as follows: “... now that he has fallen off a beam, he will not be as strong, and I have fallen off two beams, and I will fall off a third one, too, if I go out again" (BoDGÁL 1960:310). So some kind of táltos initiation motifs were known in the early modern era, which may indicate the táltos' role as a mediator in the past. Thanks to this trial record, we have two of the scarce documents regarding the helping spirit nature of the táltos horse.

In summing up the multifaceted activities and diverse belief attributes of the táltos, we can conclude that the views regarding their applied mediator techniques, ancestors, calling spirits and helping spirits, otherworlds, as well as spirit battles do not form a coherent system, and they do not help us define the distinct types of táltos; reality is less typified and stereotyped than narrative. In each region or community, a variety of traditions of wizard attributes could have coexisted, which the wizards used in their mediator practice in varied compilations as ideological backgrounds and tools, and these attributes became part of the beliefs and narrative tradition surrounding the táltos, in line with current needs and tasks. The same diversity and incoherence are

\footnotetext{
${ }_{40}^{40}$ The 1735 interrogation of Ilona Borsi in Munkács: LeHOCZKY 1887:304-305; Pócs 2016:256-257.

${ }^{41}$ For details, see Pócs 2016:255.
} 
characteristic of the early modern data regarding the performance, ritual activity, trance and transformation techniques of the táltos - although they are more lifelike, more revealing of the practicing táltos.

\section{TÁLTOS - THE SHAMAN OF THE ANCIENT RELIGION?}

Returning to the táltos construct of the pagan religion of the Hungarians, even considering the criticisms, we can state that the scholarship has been and is, in general, treating Vilmos Diószegi's theories as unquestionable axioms. In view of this, I found it expedient to present my findings on the problematic of the táltos as "the shaman of the ancient religion" in this paper, reflecting primarily on his research, presenting my research results partly building on his achievements and partly critiquing his reasoning. Thus, tentatively, I follow Diószegi's model of shamanism, seeking the criteria of shamanism in Hungarian data according to the Eurasian ideal he built based on Róheim.

The above series compiled from the táltos database does not quite fit this "shamanistic" construct; neither the modern data, nor the earlier, $13^{\text {th }}-16^{\text {th }}$-century mentions point to the typical, "classic" shaman role. At most, the survival of some of the relics of shamanism can be attributed to certain motifs, for example, regarding animal helpers, initiation, or battles, but this in itself does not prove the existence of shamanism in the religion of pagan Hungarians, at least not when we are looking for the figure and activity of the "classic" shaman in the data. Important requisites, such as the drum, the shamanic attire, and the public performance character of the shamanic séance are missing.

In my opinion, the reconstruction of the táltos of the ancient religion formed by Diószegi is rather incoherent, clearly consisting of many motifs that are not, or not exclusively, the original, distinct attributes of the táltos, but rather parts of other beliefs or ritual complexes, data taken out of context from other systems and forced upon the research construct of the "Conquest-era shaman". Furthermore, some of the phenomena that serve to prove the existence of shamanism, such as the dual soul, trance, certain cosmogonic notions - although they may have a legitimate place in a shamanism construct - are not conclusive in terms of ancient Hungarian shamanism because of their universality.

A fundamental problem with Diószegi's shamanism-reconstruction is that he did not take into consideration issues of the age, genre and social environment of the data when attempting to reconstruct millennia-old religious rituals and their functions and related worldviews from $20^{\text {th }}$-century narratives. Particularly important in this regard is his lack of distinction between belief, actual ritual practice, and the epic tradition that reflects it only tangentially and with many transpositions.

Below, following the points of Diószegi's above-quoted summary, I look at the motifs formed around the táltos as a shaman of the ancient religion, and comment on the results in light of my methodological considerations and new data, while dismissing certain non-relevant details. 


\section{Worldview and soul concepts}

According to Diószegi's summary: “The Hungarians' worldview was characterized by the Tree that Reached up to the Sky bearing the Sun and the Moon, a world of serpentslizards-frogs, souls around the world tree, the life soul and the free soul, i.e., multiple souls" (DiósZEGI 1967:134).

Data of the world tree and the stratified structure of the universe, as well as some of the features of the underworld, came to Diószegi's attention as parts of the shamanistic worldview, motivated by the world tree concepts of related peoples and the role of the "shamanic tree" imitating the world tree in shamanic initiation (Diószegr 1958a:278292). As we have seen, modern-day táltos data cannot be used to produce data of cosmogonic concepts of a practicing táltos or of the world tree/shamanic tree; the scarcity of Diószegi's data is due to this lack. The motifs from which he attempted to build a shamanistic cosmogony appear to be highly selective, and in many cases untrustworthy. (For example, his only data of a "shamanistic" journey to the underworld of "serpents and frogs" comes from the hell-vision of a Christian seer.) (Diószegi 1958a:270-275, 1967:86-87). The parallels of underworld journeys cited by him from Altaic peoples can at most be found in tales in the Hungarian material, like in the tale of Fehérlófial Son of the White Mare (AaTh 301B), so they do not conclusively prove the hypothetical shamanistic activity of the táltos. The universality of these concepts also calls for caution regarding conclusions drawn about the ancient religion: the notions of seven layers of heaven vs. the underworld cannot be associated with only the shamans of Eurasia, as they are present in Europe's alternative cultures both preceding and alongside Christianity (such as the cult of Mithras, or gnosticism).

Likewise, the world tree is also part of a widespread cosmogonic concept; it is just as present in Ob-Ugrian and Central Asian myths as it is in Europe's pre-Christian religions (Tolley 2008:I.108). Diószegi considered the type of world tree in whose crown sit the sun and moon and a bird perches on its top - which is only deduced, not supported by data from Hungarian folk beliefs ${ }^{42}$ - to be a concept that was a remnant from the Uralic era (Diószegi 1969). This perspective must also be viewed critically in light of the Tree that Reached up to the Sky with the sun and moon between its branches being a recurrent cosmic concept in Christian ritual songs of midwinter festivities - koleda, kolinda - in Eastern European folk poetry, also linked to the motifs of stealing celestial bodies or the solar eclipse. The world tree that is destroyed by underworld monsters every year and renewed during the feast of the birth of Christ is a folklore motif widespread among many peoples of the Balkans. ${ }^{43}$ This, of course, does not preclude that it was "an ancient notion of the Hungarians" and that it can be assumed to have existed in the worldview of ancient Hungarians (Diószegi 1958a:292). This assumption is supported by the life tree motifs of Conquest-era tarsoly (sabretache) plates and other archaeological finds, ${ }^{44}$ although decorative elements of everyday objects can never be hard evidence of a given

\footnotetext{
${ }^{42}$ The credibility of the three known Hungarian modern-day depictions of the world tree - recreated from the horn jars of Nagysárrét - is highly dubious.

${ }^{43}$ Kalojanov 1995: Chapters 2 and 6.

${ }^{44}$ István Fodor on the world tree with the sun and the moon, as well as the eagle, on the Iranian, Sasanid origins of the Sun-Moon motifs: FoDOR 1973:32-34, 2005.
} 
worldview. Despite this ornamentation and the táltos motifs of the Tree that Reached up to the Sky tale mentioned below, the Hungarian táltos as a practicing mediator does not seem to be connected with this supposed shamanistic cosmogony, and there is no direct evidence of such a connection in the past either.

In terms of conceptions of the soul and shamanic ecstasy, belief in a dual soul was highly prominent in Diószegi's views, which he based on north Eurasian data, according to which the free soul, capable of detaching from the body and existing alongside one or more self-souls/body-souls, played a role in the ecstatic practices of the shaman (tranceinduced "soul flights") (PAASONEN 1909-1910; PAIs 1975d). The concept of dual soul is, in some respects, a research construct, ${ }^{45}$ and it seems particularly so in Hungarian research which works with highly shamanistic assumptions ${ }^{46}$ However, based on both linguistic evidence and the later written representations and folklore of Hungarian culture, it is likely that phenomena perceived as the manifestations of the free soul may have been present in the worldview and religion of Conquest-era Hungarians. But these are general characteristics of the human psyche - and of all cultures ${ }^{47}$ - therefore they cannot be criteria for the existence of ancient Hungarian shamanism.

As for the hypothetical ecstasy of the Conquest-era shaman, as I have mentioned, the táltos battle is usually referred to in the relevant narratives as an "actual" earthly adventure. For the battle taking place in the "soul", in a trance, Diószegi has only three data (DiósZEGi 1958a:77, 295-327, 340), none of them direct, subjective supernatural experiences, but rather narrative motifs associated with stories of other (werewolftype) mediators: diviners, seers, "those born with teeth" (not just Hungarian). Diószegi supplemented his lack of data on trance from $20^{\text {th }}$-century practices of seers and diviners, as well as from the narratives of Witches 'Sabbath visions found in witch trials; he also tried to prove the presence of shamanic ecstasy in Hungarian history with examples from colloquialisms ("his soul only comes to sleep inside of him" and the like) (DiószEGI 1958a:302, 324, 339). These data do not substantiate the ecstasy of the shaman, only the universal nature of trance-induced visions, because seers, witches, healers, and even saints entered trance states: in the literature of Christian mystics, we can find abundant motifs of "the travels" of the free soul to heaven or hell. ${ }^{48}$ Diószegi's reasoning that the modern-era seer of the dead "preserved" the trance technique of the ancient Hungarian táltos is unacceptable: the seer entered into a trance in his own right; the data of his soul flight can be interpreted only in their own context, not within an artificial, "shamanistic" framework. The extremely sparse number of data of the táltos trance is explained above with the narrative tradition of the battles, and I will return to this problem below.

\footnotetext{
${ }^{45}$ See, for example, Paulson's (1958) soul concepts, or Dezső PAIs’ (1975d) word analyses. As Ulla Johansen correctly points out: the duality of the body soul + free soul is a "western" category (JOHANSEN 2006).

${ }^{46}$ See Ákos Szendrey's synopsis of soul concepts: SzENDREY 1946.

${ }^{47}$ See for example, Boyer 1986; Peuckert 1960a.

${ }^{48}$ See Pócs 1998; Holm 1982; as well as the great overviews of European visions in the Hungarian context: KaTONa 1907; in the context of late Antiquity and early Christianity: MaCDeRmot 1971. If we include the aforementioned data of mythical creatures in the Balkans that grow wings by drinking milk, we must refute Mihály Hoppál's view on the milk-drinking táltos mentioned in Note 16.
} 


\section{Birth, selection, initiation}

According to Diószegi: "The táltos candidate's selection by illness, his acquisition of knowledge through continuous sleep and the dismemberment of his body, through the details of his initiation by climbing the Tree that Reached up to the Sky, and even as a whole, sets before us the notions of the conquering Hungarians of the táltos candidate." (This includes being born with extra bones - with teeth or six fingers - which is not mentioned in the synopsis but receives great emphasis in his book.) (DiószeGi 1967:134).

We witness here the erroneous identification of birthmarks by Diószegi, which many of his critics have noticed; he blends the notions of being born with an "excess bone" and being born with teeth, and the Finno-Ugric, Turkic, and Samoyed parallels associated with them are extremely scant and very heterogeneous, thus proving nothing (DiósZeGi 1958a:25-55, 122-138). ${ }^{49}$ Nonetheless, being born with teeth is indeed one of the most characteristic features of the Hungarian táltos, and our already mentioned $18^{\text {th }}$-century data testify to this fact. However, Diószegi's data must be supplemented with other birthmarks and the wider context of birthmarks. Being born with teeth (sometimes specifically with canines), even being born with a caul, seems to be an Eastern and Southeastern European werewolf-type characteristic (along with some of the Transdanubian data of being born with bristles or fur) which also extends beyond the scope of táltos beliefs. Being born with a double set of teeth, as I have mentioned, is an attribute of double beings known throughout Eastern Europe that exist simultaneously in a living and dead form. The táltos became associated with these beings through their animal alter ego, at least at the level of narratives, but a double set of teeth can in no way be classified as an ancient Hungarian feature. Thus, being born with teeth cannot be regarded as an exclusive ethnic characteristic of Hungarian táltos, and the related data do not substantiate the táltos' being the "shaman of the ancient religion."

Diószegi distinguished the active and passive modes of selection ("forced calling, reluctance, the illness and torture of the reluctant candidate") as South Slavic or Hungarian features (Diószegr 1958a:21-39): he classified the data referring to the "passive" calling as táltos features. However, these can be just as characteristic of the South Slavic peoples whom Diószegi associated with the "active" selection process, because, in general, he relied on widespread Central Eastern European narrative motifs of the chosen ones (heroes, saints, and Christian seers). Motifs like "he has to go", "he disappears/dies at the age of seven" and similar motifs are particularly characteristic of Balkanic beliefs about werewolves and weather wizards, as well as of the HungarianCroatian-Slovenian figure of the garabonciás, so this is not the exclusive specialty of the Hungarian táltos. Data regarding the calling of the spirits only apply to the táltos in two cases (horse and bull) (DiószeGr 1958a:25-46, 59-70), but these motifs also belong to the werewolf-type narrative tradition. In this sense, Diószegi's heterogeneous group of data is not probative as it does not refer to the táltos as a shaman of the ancient religion.

\footnotetext{
${ }^{49}$ On this: DemÉNy 2000:156-157; even Gyula László did not think it was proven: LászLó 1959:447.
} 
Diószegi's arguments regarding the dismemberment, deboning, and cooking of the candidate as being remnants of shamanic initiation are also problematic. There is only a single táltos data in our tales and legends, which, however, does not actually refer to "dismemberment;" this lack was remedied by Diószegi with some tale motifs that are not quite related (The Magician and His Apprentice, AaTh 325, The Tree that Grows in the Sky, AaTh 317) (Diószegi 1958a:86-94, 140-145; Döмöтör 1988:123-125). The motifs of the shamanic candidate's dismemberment and deboning are fabulous, mythical expressions of the archaic (but not shamanistic) concept of master/mistress of animals well-known in the extended region of East-Central Europe (from the Caucasus through Asia Minor and the Balkans to the Alps) (SCHMIDT 1952).

The motif of initiation and rejuvenation by cooking is another very old remnant of several Indo-European mythologies; ${ }^{50}$ the mythical formulations known in the Balkans are mostly related to beliefs of fairies and Fates or witches. Diószegi's Hungarian data (not even applicable to the táltos) also belong in this group. They are also present in the stories of Slovenian-Croatian weather wizards of the Balkans (kresnik, vukodlak, vedomec), as well as in Balkan epics (which exhibit Altaic relations) (STOJANOvič-LafaZANOvSKA 1996). However, even considering Diószegi's Altaic parallels, it does not follow that this motif could be directly related to the existence of an ancient Hungarian shaman.

Diószegi even associated the "shamanic initiation" motif of the tale of the Sky-High or "Crownless" tree (Solymossy 1929, 1937; KovÁcs 1984; BenEdeK 2003) with the táltos: according to the sujet of the tale, this is where the táltos acquires his horse (i.e., receives a helping spirit), or, according to some variants, is dismembered and resurrected. Several scholars have expressed reservations about Diószegi's arguments: in addition to the Ugric, Turkic, and Samoyed parallels, the relevant tale motifs also have Eastern and Western European relations and are mostly of literary origins ${ }^{51}{ }^{5}$ think Linda Dégh's reasoning points in the right direction: in her view, despite its "shamanistic" motifs, the tale has no connection to the rites of the táltos, and its relations should be sought not in Hungarian but in Turkic shamanism (DÉGH 1965:22, 77-79, 1978). As Mihály Hoppál writes, the shamanic tree that reflects the world tree is "one of the main organizing principles of the worldview of the Siberian shaman" (HoppáL 2001:75), but Diószegi was not able to prove the historical existence of the shamanic or táltos tree in the practice of the táltos. Some of his dubious data of táltos trials are mythical "trial/initiation" motifs related to a number of magical specialists and are therefore not considered relics of the ritual initiation of the táltos as a practicing mediator. ${ }^{52}$ However, the question arises whether the data from the witch trial proceedings of Judit Szőcs et al. in Miskolc, which Diószegi also cites, may be referring to some kind of initiation trial related to the "shamanic tree". This and some other "initiation-like" data from the witch trials cited above establish the likelihood of the existence of certain actual "táltos initiation" data behind the many narrative traditions, as well as the actual mediator role of the táltos in the past. The small number of data and their context-poor heterogeneity do not allow us

\footnotetext{
${ }^{50}$ See Oosten 1985: The Magic Cauldron chapter.

${ }^{51}$ BLÉCOURT 2012: Jouneys to the Otherworld chapter.

${ }^{52}$ Falling out of a birch tree or a chicory bush and the like: Diószegi 1958:51-52, 90-112, 140-167.
} 
to agree with Diószegi's conclusion that the Hungarian "táltos initiation ceremony is the equivalent of the initiation rituals of related peoples" (DiószEGI 1958a:166). ${ }^{53}$

\section{The shaman's drum and headwear, the táltos tree}

According to Diószegi: "The single-headed rattling drum in the hands of the táltos, his beast of burden, the owl-feathered and horned headgear, the notched or ladder-shaped 'táltos tree,' this is the equipment of the pagan Hungarian táltos..." (Diószegi 1967:135).

The táltos tree was referred to above in connection with some "initiation-like" data, but it should be emphasized that these objects found in the "initiation-like" data cannot be classified as the tools of the pagan Hungarian táltos. The inclusion of the shamanic drum in the reconstruction of the shaman of the ancient religion, as mentioned above, intensified after Gyula Sebestyén's study. Diószegi's shamanic drum reconstruction, following in the steps of Sebestyén, Róheim, and Solymosy, ${ }^{54}$ must be deemed fictitious in its entirety. Diószegi has no data specifically related to the figure of the táltos, nor is there the slightest trace of a drumming táltos or a táltos drum in either the newly discovered historical data or the great contemporary táltos database. The secondary folklore data of the ecstasy-inducing drum, like the drum of Moldavian mummers called urálók or the phrase "iron pot is our drum" in the ritual songs called regölés, point to various Balkan (Romanian, Serbian, Bulgarian) folk customs (i.e., the Balkan cognates of regölés, ${ }^{55}$ or to rusalia and other collective possession cults and healing rituals in the Balkans) ${ }^{56}$ The sieve-shamanic drum link is also highly dubious in light of beliefs about Western European witches and mora/Mahr/mara creatures traveling to the otherworld in a sieve.$^{57}$ Bobolás - beans or corn spread over a sieve or a board - is a divination method that dates back to the Byzantium of the late Antiquity and is known throughout Eastern and Southeastern Europe. ${ }^{58}$ Sebestyén's first Vas county data on a divination using the town crier's drum, which gave rise to the táltos drum reconstruction, can be classified in this latter category. Once we remove all this background, the children's songs cited by Sebestyén, Róheim, Solymossy, Diószegi and their followers, and the metaphors

\footnotetext{
${ }^{53}$ See these motifs in the textual context of various scholars, seers, etc.: Pócs 2012a.

${ }^{54}$ See SebeSTyÉN 1900; RóHeim 1925:11; Solymossy 1937:356; DiósZegi 1958a:171-220.

${ }^{55}$ See the Balkan rituals in more detail: PuCHNER 1997, 2007; Pócs 2004.

${ }^{56}$ The trance-inducing music of rusalia and other Balkan healing possession cults is created with whistle, drum, and violin: in this, as in other Balkan ritual music, the flute, the violin and the drum are fundamental necessities. The drum of the rusalia rites is surrounded by ritualistic regulations, as it is also the instrument that initiates one into the fairy cult (see, for example, ANTONIEvić 1990:147187). In Croatian and Serbian witch beliefs, a drum is used for recruiting witches, or as a requisite in "otherworldly" witch battles or during the marching order of the enemy wizard troops - this seems to be a belief borrowed from the fairy cult (see Pócs 1989a:245).

${ }^{57}$ According to general European beliefs, these beings float in water, just as the European witch does (cf., for example, the trial by water of witches, Peuckert 1960b, Pócs 2016, Tóth G. 2001); we also have data on European witches floating in sieves, e.g., Shakespeare: Macbeth. Thus, Mihály Hoppál's Manchu parallel mentioned in Note 16 is irrelevant in terms of the táltos.

${ }^{58}$ See, for example, the South Slavic data of LiLeK (1900:65-69) and Belović (1927:132-133), or MosZYŃSKI's (1939:403-404) overview of East and Southeast Europe.
} 
of colloquialisms relating horse-sieve-drum cannot be considered as evidence of a Hungarian shamanic drum. Skepticism about this has been voiced by many ${ }^{59}$ yet the motif launched by Sebestyén is still present in all reconstructions today.

The evidence Diószegi brings for the survival of the erstwhile Hungarian shaman's horned or feathered headgear - witches that might be spotted from St. Lucy's stool (DiósZEGI 1958a:44, 227-265, 1967:82-83) - belongs to a group of divination techniques known in much of Central Europe that is related to the dead and to witches who appear at the winter solstice, as well as to the feathered masks of the Austrian-Hungarian-Slovak St. Lucy and Perchta mummeries, ${ }^{60}$ in some cases perhaps to the belief of a winged, dragon táltos. However, these data taken out of the context of their own systems do not say anything about the outfit of the erstwhile, hypothesized shaman. ${ }^{61}$ Thus, there is no credible evidence of the drum and costume of the Conquest-era shaman.

\section{Trance, spirit conjuring, battle (and helping spirits)}

Diószegi writes: "... the battle carried out in the shape of an animal while in a trance state and the exclamatory spirit conjuring (...) reveal the ancient practice of the táltos." (DiószeGi 1967:135).

As far as the terms reg/regös ('minstrel') and rejt/rejtezik ('hide/hiding') go, linguists, folklorists and ethnomusicologists alike consider the regös song a remnant of a rite associated with the shamanism of the ancient religion, based on the Finno-Ugric "shamanistic" terminology and the magical refrain formula of regös songs containing these words (Sebestyén 1902; Erdődi 1937; Pais 1975b; VARgYas 1979; DemÉNy 1994; PAKSA 1999). In my own study of regölés and its parallels in Central and Southeastern Europe, I theorized that the reg/regös word family was part of regölés, and as such, are "only" evidence of the ecstasy of the regös, rather than the existence of the shaman of the ancient religion (Pócs 2004). Furthermore, the term rejt/rejtezik ('hide') refers to someone who enters a trance state or is sleeping/dreaming alone or in a remote location away from other people, so it is quite unlikely to have ever been a term of a public shamanic performance. In the same context, the haj/hej/huj expressions have been assumed to be trance-inducing words or "spirit conjuring words" (ERDŐDI 1937; GoMBOCZ 1960; PAIS 1975a, 1970b; BALÁzs 1954; DiósZegi 1958:400-426; DEMÉNy 1994). These, like all such expressions found in the festive ritual songs of Central and Southeastern European peoples, must be excluded from the body of possible evidence of shamanism.

The battle in the shape of an animal while in a trance state - using Diószegi's expression - is a key question regarding the possible "shamanic" activity of the táltos; this is the motif of Róheim/Diószegi's reconstructed táltos notion that even the most

\footnotetext{
${ }^{59}$ See, for example, the opposing views cited by Szendrey (SzENDREy 1956); or Karjalainen's reservations (KARJALAINEN 1927:III, 263-71), or much later Demény's doubts (DEMÉNY 2000:160).

${ }^{60}$ See RóHeim 1920 (he associated the data of ox horns, feathers, etc. seen on witches with Perchta mummering); Pócs 1999: 144-147; 2019: The Ritual Techniques of Seeing chapter.

${ }^{61}$ The supposed shamanic headdress data was considered unproven even by Gyula László $(1959,1990)$.
} 
critical commentators recognize to be one of the most important and truly characteristic features of the táltos, even if they do not consider it an unconditionally "shamanistic" motif. Researchers began paying attention to the battle after Lajos Kálmány's 1917 publication (KÁLMÁNY 1917). Diószegi, utilizing Kodolányi’s synopsis (KoDOLÁNYI 1945), compiled its types and elements (DiószEGI 1958:344-352) and created a picture that is essentially consistent with what I was able to outline based on my extensive database; the only thing I had to add was the winged (dragon, eagle) type of táltos. What I find lacking in Diószegi's argument is the distinction between narrative level and reallife practice, which would be especially important in the evaluation of the narratives and narrative stereotypes of the battles.

In fact, Diószegi touched upon this issue on several occasions when he asked how we should interpret the animal shape assumed by the táltos during his battle. Based on Siberian, especially Yakut examples, he determined that it was the shaman's animal spirit, i.e., the free soul leaving the body of the táltos during trance that took on an animal form (Diószegi 1958:385-394). This may often be true for shamans of various Turkic peoples, but it is difficult to draw such conclusions from our Hungarian táltos narratives. The only ( $18^{\text {th }}$-century) táltos that went into a trance did so through the ritual technique of hydromancy and thereby "changed into a fish;" for lack of further data, we cannot even suggest any other possible options.

Although helping spirits played an important role in Eurasian shamanism, it is no coincidence that Diószegi did not delve into this subject: there are very few and very uncertain helping spirit traditions associated with the táltos. In fact, it was not he but his folktale-researching predecessors and folklorist followers that associated the táltos horse of fairy tales with the táltos. It is regretful, however, that he did not include in his investigations the táltos/garabonciás of the Southern Plain who turned into a dragon or had a dragon helping spirit; with the dragon, he would have found a more direct "shamanistic" connection than the táltos horse.

\section{WHAT THE BALKAN PARALLELS TELL US}

Diószegi is mistaken when he thinks that the táltos was the sole possessor of trance techniques or of a "shamanistic" practice that was erroneously and exclusively identified with these in the region. It is refuted not only by the existence of other types of European - and even Conquest-era Hungarian - non-shamanic mediators, wizards and seers communicating with the spirit world in a trance and through dreams, but also by the European parallels of the táltos Diószegi failed to notice. Since Róheim (RóHEIM 1925:23-25, 33-35, 1984 [1961]), we know that there are significant South Slavic parallels of the Hungarian táltos battle motifs. Unlike Róheim, however, who hypothesized a slight South Slavic influence, Diószegi did not take these into serious consideration and identified the narratives of the battles of Slovenian and Croatian wizards as another type, often Hungarian in origin. Based on my survey of the Balkan data at my disposal, it is my opinion that it is exactly these parallels that can be connected to some of the aforementioned battle- or táltos-types or rather táltos narratives, and this relationship changes the position of the Conquest-era táltos, calling into question some of its hypothesized ancient religious features or directing our attention to other possible 
approaches to the legacy of the ancient religion. Below, I will briefly describe the data of Balkan wizards relevant to our topic. ${ }^{62}$

Of the European parallels of the táltos, the most important ones are the weather wizards with trance capabilities known in most parts of the Balkans and partly in Ukraine and Poland. Much of the known data is an implied mythical formulation of a possible wizard practice, but unlike the Hungarian "shortage", there are data of "battling" wizards with trance capabilities still practicing in the $20^{\text {th }}$ century. Based on these narratives, roughly two types of wizards can be differentiated: storm wizards who battle in human form, and a group of werewolf-type wizards who turn into animals; but the reality, much like in the Hungarian situation, is much more diffuse: the storm wizard features marked all táltos types existing on the narrative level, even in the Balkans.

\section{Storm wizards}

According to storm wizard beliefs, all types of storms are distinctly "windy" and "tempestuous" in nature, and this allows the wizards to communicate with the storm demons. Through their spiritual relationship with the storm demons, storm wizards were able to control storm clouds even in their human form, from the ground, but a significant portion of narratives describe their mediator activity as a spirit battle against hostile storm demons. The data about these wizards come from Western Serbia and Southern Croatia, where they were known as stuha, zduva, zduhač, ${ }^{63}$ vetrovnjak ('windy'), and so on. Their close parallels were known in Southern Poland and Western Ukraine, too, as planetnyk, chmurnik ('cloudy'), etc. Some of their features are also borne by the mythical figures of the Croatian grabancijaš and the Romanian şolomonar, and the latter terms were also sometimes used for practicing wizards. In their case, this is a tradition that is well-established in many parts of Southern and Eastern Europe and goes beyond Slavic peoples; we have data from ecclesiastical sources from the $6^{\text {th }}-7^{\text {th }}$ centuries that mention nephodioktai ('cloud guides'), tempestatum ductores, tempestarii ('storm-controllers,' 'storm senders'), ${ }^{64}$ their distant parallels were also documented in Spain and Corsica. ${ }^{65}$

The storm demons themselves are often the souls of sinners or those who died without having been baptized or buried and could thus not enter the afterlife, taking up residence in the clouds instead. They may also have been given a role as helping spirits that protected, called or assisted the wizards in battle. Moreover, there is a great deal of data about battles between "familiar" and "alien" storm demons, or a clash of clouds led by demons, without the involvement of wizards. ${ }^{66}$

\footnotetext{
${ }_{62}$ For details, see Pócs 1996, 1999, Chapter 7. In my book (Pócs 2019, forthcoming, Weather Wizards chapter), there will be a more detailed picture of them. The first overview of these wizards, which was unknown to Hungarian researchers, came from Kazimierz Moszyński (MoszYŃski 1967 [1929]:651655). Hungarian research became aware of it thanks to Carlo Ginzburg's book on the benandanti of Friuli battling for fertility (GINZBURG 1966) and Gábor Klaniczay's study (KLANICZAY 1983).

${ }^{63}$ Their meanings are disputed.

${ }^{64}$ For a more detailed description of these, see Pócs 2019 (forthcoming), Weather Wizards chapter.

${ }^{65}$ See, for example, the Spanish nubeiro or tempestario: Pedrosa 2000; the Corsican lagramant and mazzeri: MulTEDo 1982.

${ }^{66}$ See in greater detail: Pócs $2012 b$.
} 
Stuhas were often seers and healers in one person, but their main task was to provide favorable weather for their communities. ${ }^{67}$ Although the reports are mostly about men, some data suggest that women and children may have been stuhas, too (MoszYŃSKI 1967[1929]:653). The existence of a large number of data from the last century suggests an actual practice. When the storm approached, the wizards, hiding in a secluded place, fell into a deep sleep or trance, and their so-called "translucent", "light" "shadow" similar to mist or fog left their bodies and rose to the clouds; they reached the cloudworld by becoming one with the wind, with the descending fog or mist. According to other interpretations, when a thunderstorm was approaching, the stuha physically vanished from the sight of eyewitnesses in a descending cloud or in a fog: the storm cloud "snatched him up". The notion of disappearing in the cloud also appears in the narratives as a metaphor for the final death of the wizard.

The souls of wizards who became like them joined the storm demons in the spirit battles, usually en masse. The battle was against the wizards and/or demons of other lands, other peoples, foreign countries. According to some Serbian and Bosnian data, the battle-bound wizard called upon his helping spirits, while according to other data, he prayed to his guardian angels. The goal of the battle: to redirect the advancing ice clouds to the enemy's land, or to send ice clouds to damage the crops and vineyards of an internal enemy out of revenge. The enemy combatants battled with trunks of uprooted trees, logs of wood, or sharpened pine branches. The battle was accompanied by a galeforce wind storm, its path marked by uprooted trees and demolished houses. Meanwhile, the wizard lying unconsciously or in a deep sleep could not be awakened. The stuhas of Montenegro, as they participated in the aerial battle, cried out in their sleep, made fighting gestures, ${ }^{68}$ and awoke exhausted, worn out by the battle.

The Serbian-Croatian connections of the windy, stormy táltos, their group storm battles, and the ways they were snatched up by the storm cloud are obvious - the similar motifs of many storm táltos narratives are a testament to this. Presumably, these types of the Hungarian táltos were shaped by influences from our South Slavic or even Ukrainian or Polish neighbors, perhaps from the Slavic people living here at the time of the Conquest. Besides the treasure-seeing practice that probably only dates to the early modern era, the most active features of the Hungarian táltos seem to be "storm táltos" and "windy táltos" attributes; some of the data of practicing storm táltos in the táltos trials seem to suggest this as well. Another related feature is that practicing wizards can be women and children. All this requires a lot more research, but we can confidently state that the beliefs and narratives of storm táltos with clear European parallels can hardly be projected back to the supposed ancient Hungarian shaman.

\footnotetext{
${ }^{67}$ Main sources of data on storm wizards: MosZYŃSKI 1967 [1929]:653; ĐoRĐEVIĆ 1953:237-250; BošKović-Stulli 1960:284-286; ZeČević 1981:149-151; TolstoJ - Tolstaja 1981; BurkhaRT 1989:83-84. For a more detailed description and literature, see Pócs 2019 (forthcoming), Weather Wizards chapter, with additional literature.

${ }^{68}$ ZEČEviĆ 1981:152.
} 


\section{Duels to ensure fertility: werewolf wizards}

Kresnik/krsnik, vedomec, vukodlak and similar names ${ }^{69}$ designate primarily Croatian, Slovenian and Serbian wizards ${ }^{70}$ (including a type of the stuha/zduha/zduhač wizard). Their purpose was to ensure the grain, fruit or grape crops of their communities, which they had to reclaim from the harvest-stealing dead or hostile wizard souls in "spirit battles". In addition to their storm wizard attributes, they also have specific werewolf traits, which have already been mentioned in connection with the táltos: birthmarks of teeth, wolf tooth, wild boar tooth, caul, fur, bristle, tail, the ability to turn into animals, animal alter ego, and calling animal spirits. Furthermore, there are certain motifs exclusively related to these "werewolf wizards": battling in animal form in an earthly otherworld under the protection of animal spirit guides partly identical to their own animal form, as well as a certain initiation motif, which, being familiar with it from the context of Eurasian shamanic initiation, Diószegi sought to find for the táltos as well: dismemberment-bone removal-re-assembly/resurrection, and the cooking, ingesting and vomiting up of the candidate. This mythical tradition, which exists in the Balkans and around the Alps regarding various mythical creatures, also appears as the initiation of the Slovenian vedomec wizard by his animal ancestors. ${ }^{71}$

The goal of battles in animal form is most often to fend off the attack of crop robbers; sometimes it is the actual acquisition of grains, grapes and fruit. The animal alter egos of the wizards are varied: dog, bull, ox, horse, boar, goat, lion, bear, horseshoed pig, etc. Their opponents are the "dead" forms of shapeshifters with the same name, or the enemy wizards of neighboring territories or foreign peoples who also turned into animals. Their activities are aligned with the agricultural or death cycles of the Christian calendar (winter solstice, St. George's Day/Pentecost, summer solstice, etc.) and can be linked with the archaic myths of the abduction and restoration of the grain harvest (Proserpina myth).

The community tasks of kresniks included healing and divination, as well as treasure seeing, treasure hunting, or unwitching. A majority of the narratives is about battles taking place in the earthly environment, but even the most recent collections attest to the actual community practice of wizards alongside the narrative tradition: during the aforementioned agricultural holidays, wizards would enter a trance or "fall asleep" in a secluded spot and their souls would leave their bodies for the otherworldly battle. ${ }^{72}$ In addition, there is no shortage of narratives of duel-like earthly/physical battles familiar from the Hungarian táltos narratives. ${ }^{73}$

${ }^{69}$ The meaning of the word kresnik is disputed - it may mean "border guard"; the other names refer to a werewolf ('man-wolf') (see in more detail: Pócs 2002).

${ }^{70}$ The most important publications: BošKović-StUlLi 1960:278-290; Krauss 1908:11-12; KeleminA 1930:35-40, 89-93, 245, 273, 339-344; MiKAC 1934:195-197; ĐORĐEVIĆ 1953:237-250; ZEČEVIĆ 1981:149-151.

${ }^{71}$ Kelemina 1930:12; Stojanović-LafazanovsKa 1996:79-90. These motifs are unequivocally considered initiation motifs - even if not necessarily a shamanic initiation. See, for example, Ginzburg's analysis: GINZBURG 2003:227.

${ }^{72}$ The healing and simultaneously weather practices of kresniks were also remembered by Luka Šešo's Croatian informants 10-15 years ago (ŠEŠO 2000/2003).

${ }^{73}$ Verbal communication by Uršula Lipoveć-Čebron from her Croatian dissertation manuscript written in 2000. 
Perhaps it is clear from this brief overview that Róheim was right to see a connection between the táltos and the kresnik and others. ${ }^{74}$ The Hungarian beliefs and narratives of a dueling táltos fit well into this Central Southeastern European werewolf tradition, which is presumably due to Conquest-era Slavic influences. However, there is no way of knowing whether it was a narrative tradition or an actual practice of wizards that the Hungarians adopted from their Southern Slav neighbors, or from the Slavic populations that were in Hungary at the time of the Conquest. The difference between the otherwise very similar Hungarian, Slovenian and Croatian beliefs and narratives is that the werewolf motifs are more coherent in the Slavic material, which corroborates the theory of Slavic transmission. It is conspicuous that the Hungarian táltos has no attributes of fertility magic; the goal of the duel of bulls or stallions, according to the narratives, is still the elimination of thunderstorms. The storm magic features characterized all types of táltos. Nevertheless, the dominance of bull and horse figures in the Hungarian material is striking in comparison with the various animal breeds of the South Slavic narratives. Is this a kind of "retained", specific ancient Hungarian (practicing wizard or epic) tradition? Was there such a substratum which was later absorbed into the Slavic European "werewolf" milieu? This would partially corroborate Róheim's and Diószegi's view regarding the battle, which they supported with Yakut and Buryat parallels.

\section{Dragon people}

A particular type of werewolf-like wizard is the wizard called dragon, serpent, dragonman, winged one, or dragon's son, ${ }^{75}$ who, like the Hungarian winged, dragon táltos, is also a storm wizard. The data for this come from eastern Serbia and western Bulgaria, as well as Macedonia. Some Romanian data suggest that such wizards might have practiced there as well (or that their stories were known to them), but their significance must have been much smaller than in the southern Slavic territories. In Albania, the dragon-man who fends off a hailstorm is an epic hero. ${ }^{76}$

It is a general view in Bulgaria and Serbia that this wizard's father is a dragon or a winged serpent, perhaps an eagle, hawk, crane, rooster, or gander, and that he is born with tiny wings, tufts of fur, feathers, or in a snake skin, perhaps with a caul. Pregnancy is often abnormally long, or perhaps the infant is nursed by an animal. Following his birth, the wizard child immediately begins to speak and begins his mediator activity; he may even come out of the cradle to go right into the storm battle (Albanian epics talk about infants fighting in their cradle and urinating on their dragon opponents). He grows

\footnotetext{
${ }^{74}$ This connection has been raised by Zmago Šmitek (ŠMITEK 2003), without addressing the question of "priority".

${ }^{75}$ Bulgarian zmej; Serbian zmaj, zmija, hala, ažder, zmajevit/halovit man, etc.; Macedonian zmej, zmev, zmiv.

${ }^{76}$ Overview of the zmej wizard and its kinship circle: MoszyŃsKi 1967 [1929]:578-580, 654-655. Bulgarian data: MARINOV 1914:207-209; VAKARELSKI 1969:233-234; DuKOVA 1970:235-238; GeORGIEVA 1983:79-85; BenOvsKa-SĂBKova 1992; Serbian data: ĐorĐEVIC 1953:248; SchneEWEISS 1961:13; ZeČEviĆ 1969; 1981:63-85, 149-151; Tolstoj - Tolstaja 1981; Macedonian data: VRAŽINOVSKi 1995:37-46, 46-50; Romanian data: PAMFILE 1916:314; SCHOTT - SCHOTt 1971:309; MuşLEA - BîRLEA 1970:182-189; KARLINGER - TURCZYNSKI 1982:63-65.
} 
up fast, has enormous strength and superhuman speed, may even fly, and defeats the strongest athletes in wrestling.

The cloud-world of dragon-men and eagle-men is populated mostly by the guardian spirits of dragons, eagles, and other birds bearing the same name as the wizard, who, as "good" storm demons, ensure favorable weather, protect their people from hailstorms, and are also the personal helping spirits of the wizards. Some Serbian and Bulgarian versions sit in oak trees and consider the oak tree their property, or another version is the eagle or dragon-serpent that lives on top of the mountain. In Bulgarian beliefs, the eagle, dragon and crane also appear as clan ancestors.

In some Bulgarian and Serbian villages, dragon-men were practicing wizards up until the early $20^{\text {th }}$ century: some narratives claimed that they protected their communities in the shape of a dragon or bird from the dragon-shaped storm demons that brought hailstorms. When an ice cloud approached, they retreated to a secluded spot and spontaneously fell into a trance, their acquaintances sometimes guarding their lifeless body. According to some Serbian data, their souls left their body in the shape of a serpent, while other sources claim that a dragon, eagle, or other bird snatched them up, or perhaps even the storm cloud itself as a calling spirit, or that they "vanished" for a while in the cloud the way storm wizards did. The spirit battles were fought between the dragon guardian spirits of two neighboring areas, or with the "water" dragons that came out of ponds, marshes or caves and brought hail. Good dragons were often led by St. Elijah, or sometimes by St. George. In the battles between familiar and alien dragons, the dragons were defending their village, their "sons", from the neighboring, hostile dragon: they chased away the ice clouds brought there by the alien dragon. They shot at each other with lightning arrows or used uprooted tree trunks as weapons. Their aerial battles were accompanied by wind storms, lightning, thunder, and hail.

The wizard's soul joined the aerial battle of the guardian spirits in the shape of a serpent, lizard, dragon, winged serpent, eagle, gander, or rooster. It was usually a group battle involving several wizards; the souls of the hostile wizards of alien communities could also join the ranks of the enemy. ${ }^{77}$ According to some of the data on Bulgarian spirit battles, the young versions of avian guardian spirits (including the serpent-turneddragon variant) played the role of individual helping spirits to the battling wizard spirits as specific animal or avian zmei. These eaglets, baby serpents, chicks and other baby animals, similarly to human-like $z m e i$, were born with excess animal body parts, such as double wings. All these motifs partly appear in the traditions of the Croatian/Hungarian grabancijaš/garabonciás and the Romanian şolomonar weather wizards with certain epic transpositions, but this issue cannot be detailed here. ${ }^{78}$

The Turkic origins of the Bulgarian dragon wizard, especially in light of the epic traditions to be discussed below, are unquestionable, although we can only talk about a certain independent, clearly defined wizard type and its Bulgaro-Turkic origins with a certain degree of hesitancy. Many layers of traditions have been blended in the Balkans in many ways, and, as I have said, certain general South and Southeast European storm wizard features are present in the beliefs and narratives of all types of weather wizards. However, like certain storm wizard attributes, werewolf traits also appear in the beliefs

\footnotetext{
${ }_{77}$ This is a general feature of the battles of wizards with werewolf characteristics.

${ }^{78}$ Pócs 2019: Weather Wizards as Mythical Heroes: Grabancijaš, Garabonciás, Şolomonar chapter.
} 
of all sorts of wizards in the Balkans (as they do in táltos beliefs). Reciprocal influences and the exchange of cultural goods were a continuous practice here, even after the Bulgarians' appearance in the $7^{\text {th }}$ century. Yet, it can be said that among the werewolf-like weather wizards extant from Albania to Romania, the dragon wizards definitely seem to cluster in Bulgaria. If we assume, perhaps justifiably, the existence of a past BulgaroTurkic weather wizard as the "ancestor", it would have fit into the Slavic traditions of the Balkans in parallel with linguistic integration, even if its features differed somewhat from the practices of the Slavs of the area at the time.

A meticulous analysis of the Turkic parallels and determining whether this weather magic practice can be considered a remnant of an erstwhile shamanism is yet to be done. ${ }^{79}$ (Bulgarian researchers consider this tradition shamanism, or rather as a relic of Thracian and Slavic shamanism, if they consider it at all, as possession cults like rusalia and nestinarstvo command much more scientific interest. ${ }^{80}$ )

As for the táltos, the sporadic data of winged, dragon-like táltos found in the $18^{\text {th }}$-century witch trials from Bihar and Békés counties fit into the tradition of the much more coherent Bulgarian-Serbian dragon-man traditions. Presumably, the beliefs of being fathered by a dragon or another animal, birthmarks of feather or wing, extraordinary abilities in infancy, the sporadic appearance of the crane, rooster or fish as spirit animals or animal alter egos besides the eagle and the dragon, the battles between dragon guardian spirits or storm clouds (and perhaps the Conquest-era owl-headed staff, ${ }^{81}$ as well as the belief of the owl as a "táltos bird") belong in this same group, although the latter are not part of the winged táltos motif. The beliefs surrounding the táltos are, however, much less rich; they do not form a coherent system, and they can be correlated with each other only in light of the Bulgarian parallels. Besides the $20^{\text {th }}$-century narrative tradition, we are only aware of a few practicing táltos in this group (from the $18^{\text {th }}$-century táltos trials: the above-mentioned girl from Miskolc who turned into a fish while in a trance, ${ }^{82}$ and a couple of táltos women from Debrecen and Jászberény who mentioned a dragon helping spirit ${ }^{83}$ ).

A wide range of lidérc (nightmare) beliefs also contribute to the Hungarian táltos' possible Bulgarian connections. Their similarity with the Bulgarian complex suggests that some of the features of the liderc may have retained traces of the helping spirits of wizards battling for the weather, but this is a subject for a separate study and cannot be detailed here.

\footnotetext{
${ }^{79}$ For lack of space, we cannot address the abundant Altaic parallels of all motifs (for example, world tree with eagle, battles in the shape of animals, animal spirit guides, animal ancestors, etc.). Just one Bulgaro-Turkic data: according to a 10th-century report by Ibn Fadlán on the Bashkirs, some worship a serpent, another group a fish, and a third a crane; in the battle, the serpent or crane protected them; according to another account of Ibn Fadlán, travelers saw cloud battles in the sky at dusk, etc. (ToGAN 1939:36-37, 51-54).

${ }^{80}$ See, for example, the only overview of Bulgarian shamanism, where (along with epics and archaeological relics, as well as rusalia and other non-relevant rituals) this wizarding practice is only secondary: KALOJANOV 1995.

${ }^{81}$ See FodOR 2005:15-16.

${ }^{82}$ There are two current-day data from Eastern Hungary of a baby transforming into a fish.

${ }^{83}$ See in greater detail: Pócs 2016.
} 
The common motifs of Bulgarian and Hungarian dragon-like weather wizards point to their commonly shared Bulgaro-Turkic past. It is conceivable that this kind of weather magic practice, or just the beliefs of wizards, was adopted by the Hungarians (or only a part of the Hungarians) from the Bulgarians, or during the close HungarianBulgaro-Turkic contacts from the $5^{\text {th }}$ century onwards, or, more likely, at the time of the Conquest from the Bulgarian population stranded in the southern Maros Valley. ${ }^{84}$ (The newer, Bulgarian-Slavic relationship was probably built upon Bulgaro-Turkic influences arriving in several stages.) Of course, other Slavic influences can be assumed in this case as well. It is unclear whether the assumed Bulgarian influence extended to all Hungarians, or just to the said, geographically confined space, and we also do not know what its role was in Hungarian public life. The Hungarian táltos may have been similar to Bulgaro-Turkic weather wizards, or he may just have been one type of táltos.

In order to clarify the Bulgarian-Hungarian relations, it is worth examining the part of the epic tradition of the Balkans where the roots of wizard-related beliefs lead. These include the epic songs that describe the wizards' activities, as well as the mythical songs of battles against dragons who capture girls, and the heroic epics about battles against the Ottomans, all of which were full of archaic motifs and symbols of dragon-men and dragon battles. ${ }^{85}$ This epic (also partly known among the Serbs) existed in Bulgaria for a long time alongside and closely related to the weather magic practice, corroborating the common roots of the mythical and belief contexts of wizards and epic heroes.

Each of these types of epic songs has a dragon-like hero that wins the battle against a hostile, inferior dragon that is often a "water" dragon. In terms of their origins and birthmarks, these heroes are just like dragon wizards: they are fathered by a dragon, eagle or falcon, such as the Bulgarian Zmejče Mihailče, the Serbian Janko Sibinjanin (János Hunyadi) and Zmaj Despot Vuk, also known as Zmaj Oganj/Ogneni Vuk ('dragon and fiery wolf'), the Serbian-Bulgarian Miloš Obilić, Marko Krali/Kraljević, Banović Sekula (János Székely) and others. ${ }^{86}$ There are also heroes among them who were born as twins, nursed by a mare, or raised by fairies, and their birthmarks are some of the same animal traits as those of wizards: born with eagle wings, wolf paws, or wolf fur on their arms, fire coming out of their teeth, or with a saber-shaped mark on their groin signaling the birth of a military hero, or with an "extra body part", such as having more than one heart. Animal traits and the capability of transforming into animals are characteristic of each; for example, despot Vuk could change into a falcon, eagle or wolf

\footnotetext{
${ }^{84}$ See GYÖRFFY 1977:131.

${ }^{85}$ The most complete overview of Balkan heroic epics linguistically accessible to me was Dagmar Burkhart's book (BURKHART 1968), in which the author devotes a large chapter to two important groups relevant to us: the Heldenkindlieder and the aus dem Zmej entwickelten Drachentöter groups, and also addresses the relationship between wizard traditions and heroic epics.

${ }^{86}$ Hungarian heroes have also made their way into the circle of Bulgarian-Serbian heroic epics of dragon wizards. Several scholars have dealt with these Hungarian-Serbian-Bulgarian relations and the possible ways of transmission; see, for example, JUNG 1990; CsíkHELYI 1984 (he addresses the motifs of Bulgarian epics related to the Toldi and Kinizsi legend traditions, as well as the mediating role of the Bulgarian population of the Szerémség/Srem in one-time Southern Hungary; cf. with our hypotheses on dragon wizards).
} 
during battle. A typical motif of the epic songs about battles against the Ottomans is the fight in the shape of a fiery eagle/dragon/falcon with the enemy appearing in the shape of a water dragon or serpent of the underworld, but the bird-serpent, eagle/falcon/ dragon-serpent, or any superior animal (i.e., familiar fighter)-inferior animal (i.e., alien fighter) appears in both types of epics. Before the battle, epic heroes also go into a deep sleep (the so-called magical sleep motif). Helping spirits give them strength for the battle: in Bulgarian epics, it is mostly a dragon (as in the practice of wizards) or a winged horse; in Serbian epics, a fairy, or a 'fairy horse' (vilovit) sent by the fairies (the former transforms from a lizard, serpent, chicken or fish into a winged, flying creature, the latter from an old nag into a five- or six-legged magical horse). The magical horses of the epics appear sometimes as the heroes in animal shape, or as the heroes' helpers in the fight against the Ottomans, and other times as the four-winged or eight-winged mythical stallions carrying the heroes, flying across the universe, "counting" the stars (BURKHART 1967; 1968:451-455; ZeČEviĆ 1969:364-365; LORD 1971; ČAJKANOVIĆ 1973; LoRd 1986; BenovsKa-SăbKova 1992:190-196; Kalojanov 1995, Chapters 2 and 6; Petrović 1999:597-663).

In epics about the spirit battles of wizards, the heroes - with the support of St. Elijah fight the enemy dragon by transforming themselves into an eagle or fiery dragon. In the Bulgarian parallels of the Fehérlófia/Son of the White Mare tale, and in an epic with a similar sujet, the world tree (with an eagle or dragon perching on its top) also appears: the serpent attacking the eaglets in the nest on the top of the tree is killed by Milos Obilić or another hero. As Katalin Benedek, among others, points out: there are Western European parallels for the motifs of both animal fathers and women rescued from a dragon or the underworld (BENEDEK 2007); the decisive factor here is the combination of motifs that links the adventures taking place at the top of the world tree and at its roots, which does not occur in Hungarian tales. ${ }^{87}$ Let us add: the pictorial representation of the eagle-serpent battle is widespread among Bulgarians. It can almost be considered an iconographic cliché: in some representations, the eagle is at the top of the (world) tree, the serpent at the root of the (world) tree. ${ }^{88}$

Albert Lord calls attention to the series of motifs of Bulgarian epic songs with a sujet similar to that of Fehérlófia, about Marko Krali and Huntsman Ilija: the hero receives extraordinary strength from his fairy mother and later, out of gratitude for saving the fairy's children, a magical horse; a winged horse or a falcon are his helpers during his trip to the underworld, he falls into a deep sleep before the dragon battle, kills the threeheaded dragon that swallowed the deer stag, which then comes out of the dragon's stomach alive; in other versions, the dragon swallows the hero, and then he coughs up the deer stag or hero he swallowed alive. Lord considers these motifs (world tree with eagle, acquisition of animal helpers, ingestion and regurgitation of the hero, i.e., his initiation in the world tree, dragon battles) shamanistic and speaks explicitly of ProtoBulgarian traditions (LORD 1986). The closest parallels of this series of motifs are found

\footnotetext{
${ }^{87}$ As pointed out by Vilmos Voigt in his article "Life and the Tree of Life", published in the trial issue of Világfa (n.d.)

${ }^{88}$ See the relevant images of Georgieva (1983) or Kalojanov (1995).
} 
in the same place where Hungarian researchers also found the parallels of the Fehérlófia tale: ${ }^{89}$ in the Altaic epic, more specifically in the Kyrgyz Er Töštük epic. ${ }^{90}$

Even if the motif of the dragon battle naturally differs in the case of the practicing wizard and the epic hero, the commonalities of epics and the wizard practices of dragonmen are obvious: the "shamanistic" role of animal ancestors, animal attributes, animal helpers, and the world tree. In the context of the Bulgarian winged wizard, these are all connected: in Bulgarian epics, the flying horse that carries the hero fathered by a dragon or eagle across mountains and valleys, even up to the top of the world tree and into the stars, appears as a variant of the dragon or eagle spirit animal. Hence, in ancient Bulgarian culture, there was a correlation between "shamanistic" practices and "shamanistic" epics. These correlations do not indicate a unidirectional influence: the epic elements of the dragon battle are also likely to have had a bearing on the mythology surrounding the figure of the weather wizard. This trend can be observed particularly in the motifs of miraculous births and birthmarks, and it also includes the transposition of the weather magic practice onto the Turkish enemy, or onto any kind of earthly or military action (as we have seen, the Hungarian táltos were no strangers to this either when they were fighting for the "empire" against the German táltos).

As we know, many of these Bulgarian "shamanistic" motifs are also present in Hungarian folktales (Son of the White Mare, Dragon Family, The Tree that Reached up to the Sky), and since Solymossy, they have been presumed to have "Turkic" origins. But the Hungarian folktale motifs are independent of the supposed practice of the táltos, and even of the beliefs associated with it; it is an independent epic tradition which the Hungarians may have learned about along with the practices of dragon wizards or independently of them. The fact that a large part of the "shamanistic" motifs of Bulgarian epics are known here only as fragmented narrative elements embedded not in the narratives of dragon wizards but rather elsewhere suggest an epic tradition that is different from the táltosmediator and one that came to us in another way. Such elements include: a relationship with the world tree, the initiation in the shamanic tree, or underworld journeys (elements of the "shamanistic cosmogony" outlined by Diószegi), the wizard's animal ancestor, or the "initiation" motif of dismemberment/ingestion and resurrection, as well as the motifs of the táltos horse. In addition to the Bulgarian and Serbian textual parallels, the textual motifs of táltos horses flying from mountain to mountain from the eastern part of the Hungarian language area (especially those related to Saint László) reinforce the hypothesis of a separate textual tradition. Yet, in addition to this Turkic tradition, there was probably a stratum where the practicing táltos and the táltos horse as a helping spirit were more closely related, such as in the two aforementioned $18^{\text {th }}$-century táltos trials where the horse appears specifically as the helping spirit of the mediator-táltos.

\footnotetext{
${ }^{89}$ See: DöмӧтӧR 1988:65-69 (AaTh 301B; 250/MNK 476A× János Szekfühajú); SolYмossy 1931:123, 1937:372-374.

${ }^{90}$ On Turkic and Mongolian parallels: BenedeK 2007; its close links with the Kyrgyz and Kazakh epics of the hero Töštük: SOMFAI KARA 2007. The motifs of the Er Töštük epic quoted by Lord: the hero goes into the underworld in search of a giant black eagle that has abducted a newborn foal. He chases the eagle all the way to the bottom of the giant world tree, on top of which sit the giant eagle's eaglets; these are threatened by the dragon-serpent at the foot of the tree. Töstük cuts the dragon into pieces, ties the pieces to himself, climbs the tree and feeds the eaglets with the dragon pieces (LORD 1986).
} 
The dilemma of whether this was an actual wizard practice or an epic expression, as well as the question of the origin of this duality, has been raised on several occasions in Hungarian scholarship (I mentioned above Lajos Vargyas' and Vilmos Voigt's concerns regarding the motifs of the táltos duel, táltos horse, dragon battle, and the Tree that Reached up to the Sky) (VARGYAS 1985:41-42, 1988:407-413; VoIGT 1998:153-154). Aladár Bán, János Kodolányi, and Mihály Hoppál considered the struggle motifs of the Toldi legend as evidence of Toldi being a táltos, but they did not pose the question whether it was a practicing táltos or an epic motif (BÁN 1917; KODOLÁNYI 1945; HoppáL 1981). In this regard, I agree with Vargyas and Voigt, based on the countless data of táltos who fought earthly, duel-like battles and not otherworldly spirit battles: it may very well be that the táltos battle was, at least partly, merely a textual folklore tradition or a heroic epic motif in Conquest-era or earlier Hungarian culture. ${ }^{91}$ Many things suggest correlations with heroic epics, not in the least the above-mentioned male-female distribution among the táltos of the epics and the wizard-táltos. I cannot, however, support the idea of Pál István Demény that extrapolates from the motifs of táltos duel, táltos horse, etc. a Hungarian Conquest-era heroic epic in which heroes mounted on a táltos horse wrestle with demons in an archaic world, in the center of which stands a world tree through which the upper world, and at its roots, through an opening, the lower world can be reached (DEMÉNY 1997:162-163). According to our present knowledge, this is not an erstwhile Hungarian heroic epic but a Bulgarian epic that is in existence to this day! There is no telling whether there was a similar Hungarian heroic epic, just as the past activity of the winged dragon wizard cannot be deduced from the sparse data. What can be established is that epic motifs, just like wizard practices, have first and foremost parallels in the Balkans, Balkan parallels that strongly support the possibility of direct Bulgaro-Turkic or even Bulgarian-Slavic influences, even in the case of epic genres and motifs.

Another question, which would be difficult to answer, is whether it was the Bulgarian "shamanistic" practice, or the Bulgarian heroic epic, or the Bulgarian folktales, or all of them simultaneously that the Hungarians adopted in the era of Bulgaro-Turkic interactions. The epic tradition, as well as the tradition of dragon wizards, could have reached Hungarian culture in several stages, through various fusions with Slavic weather magic practices. It is certain that these multiple layers of tradition were important determinants of medieval (and partly perhaps even Conquest-era) Hungarian religious life.

I must refer here briefly to the origin myths of the Árpád clan: the motif of conception by an eagle (turul), which is generally interpreted as a remnant of totemism. ${ }^{92}$ This motif has undeniably something to do with the tradition of Bulgarian heroes and wizards, as well as eagles, cranes, falcons, etc. as guardian spirits and/or ancestors of clans. We know that Béla Gunda attempted to reconstruct an ancient Hungarian totemism based on scattered data of Hungarian táltos fathered by animals (Gunda 1963). Despite Gábor Vargyas' justified refutation (VARGYAS 1997), in a roundabout way and supported by the Bulgarian parallels, we may still arrive at totemism, even if not a Hungarian totemism

\footnotetext{
${ }^{91}$ Data of the shamanism of various Turkic peoples suggest that the ritual activities of the shaman and the associated battles while in a trance and their epic representation as an earthly battle can coexist within the same community. Epic representation does not mean it is secondary! (See, for example, KSENOFONTOV 2003:269-281; KENIN-LOPSAN 2003.)

${ }^{92} \mathrm{Cf}$. for example Fodor 2012.
} 
at the time of the Conquest, but at an erstwhile totemism of the Bulgaro-Turkic peoples, the reinterpreted fragments of which, intertwined with the remnants of shamanism, were preserved among both peoples, even in the Christian milieu. ${ }^{93}$

\section{WAS THERE A HUNGARIAN SHAMAN AT THE TIME OF THE CONQUEST?}

In summary, it can be said that if the above-mentioned weather wizards are considered shamans, the existence of a hypothesized Conquest-era Hungarian shamanism seems more likely in light of the Bulgarian data than through the examination of the Hungarian traces on their own, or even on the basis of the distant Altaic or Finno-Ugric similarities. The beliefs and narratives of the modern era show a number of correlations with the Balkan data; the táltos is much closer to the wizards of the Balkans than to the far-flung parallels assigned to it in the Róheim/Diószegi construct. The influences on Hungarian culture coming from here are certain, and at least in part can be dated after the Conquest. Hence, there may have been a mediator who practiced weather magic around the time of the Conquest and whose figure and activity might have somewhat resembled the Hungarian táltos and the Bulgarian weather wizard. We can also count on a Slavic storm wizard practice and the great influence of Balkanic werewolf beliefs, possibly "werewolf wizard" practices and/or narratives. Obviously, whatever the Conquest-era or medieval Hungarian táltos was, it had Turkic traditions that had been incorporated into this Slavic/ European milieu, as a result of which we can still encounter traces of diverse, multirooted táltos activities (or at least multi-rooted epic traditions).

The question is whether the inferred weather wizard can be classified as a shaman, and his supposed activities as shamanism; would this have been "the" Hungarian shaman? There is no trace of a non-weather wizard in Hungarian culture, and hard evidence only points to the mediator activities of a weather wizard (beside the treasure-seeking táltos that we have data for from the $18^{\text {th }}$ century onwards). The regulation of precipitation could have been one of the shaman's tasks, but it also could have existed in addition to the shamanic role, as an independent function. ${ }^{94}$ In fact, it is up to the researcher to decide whether such a wizard - one who communicates with the supernatural in a trance and makes spirit journeys, if not into the heaven and the underworld, at least to an earthly cloud-world, fights hostile demons, and perhaps even has helping spirits - can be considered a shaman. If the answer is yes, we forsake several of the criteria that are defining features of European shamanism, including the characteristically public ritual performance and various other symbolic requisites of the "classic" shaman. However, if the Conquest-era Hungarian shaman was like the modern-day South Slavic wizard who retreated into solitude and was in contact with the storm demons of the cloud-world,

\footnotetext{
${ }_{93}$ Among the Bulgarians, perhaps even traces of a totemistically based social organization may be found.

${ }^{94}$ In terms of Altaic and North Siberian shamanism, see the various magical/religious specialists, various diviners and possessed, including the weather wizard, and the "cumulation" of shamanic tasks, which also included weather magic. There were Turkic and Mongolian shamans who performed weather tasks, just not in a trance, but rather through analogical magic with rain stones; there is no evidence that they had the capability of falling into a trance: JOHANSEN 2006:149-151; VerBICKIJ 2003; BOYLE 1972.
} 
then his activities strongly diverged from the public ritual of drum-induced ecstasy hypothesized by researchers. If this was the kind of shaman we had, we should not think of him as playing a central role in Conquest-era society, or even fulfilling a priestly function, and least of all as "shamanistic aristocracy". 95

Thus, the nostalgic search for the attributes of the Eurasian "classic" shaman constructed by Róheim and Diószegi must be abandoned, it seems. Rather, we should further investigate what other kinds of non-shamanistic magical/religious specialists might have existed in the Conquest era in addition to the weather wizard - diviners, seers, clairvoyants, regös - who might have employed trance techniques without being shamans. Behind the terminology referencing trance techniques lies primarily regös/ regölés: in my already mentioned study on regölés, I demonstrated that it is not impossible - although it cannot be proven with hard data - that at the time of the Conquest, perhaps due to Byzantine Christian influences, the "predecessors" of the regös were some kind of possession-cult practitioners, independent of the hypothesized ancient Hungarian shamanism. The regös cannot be considered a shaman in the "classic", Eurasian sense of the word, but as a different type of mediator, a "possessed" healer, he may have been a significant factor in Conquest-era Hungarian religious life. ${ }^{96}$

If, however, we still wish to seek the representatives of "classic" shamanism - á la Róheim and Diószegi - at the time of the Conquest, we should recognize the fact that, besides the absence of any trace of the shamanic ritual they have reconstructed, regölés, which preserved the terminology of ritual trance and many early medieval textual and ritual elements, survived well into the early $20^{\text {th }}$ century. In view of this, some remnants of the public rites of drum-induced ecstasy - if they existed in the Conquest-era - should have been preserved as well.

\section{REFERENCES CITED}

Antoniević, Dragoslav

1990 Ritualni trans [Ritual Trance]. Beograd: Srpska Akademija Nauka u Umetnosti Balkanološki Institut.

BALÁzs, János

1954 A magyar sámán révülete. Rejt, rejtëk, rejtëzik [The Trance of the Hungarian Shaman. Rejt, rejtëk, rejtëzik (Hide, Hideout, Hiding)]. Ethnographia LXV:422-425.

BÁN, Aladár

1917 A Toldi monda alaprétege [The Basic Layer of the Toldi Legend]. Ethnographia XXVIII:21-35.

Belović, Jasna

1927 Die Sitten der Südslawen [Customs of the South Slavs]. Dresden: Paul Aretz Verlag.

\footnotetext{
${ }^{95}$ On the supposed social role of the Conquest-era shaman and calling into question his central role: VARGYAS 1978; DienES 1981; LÁsZló 1990; FODOR 2003, 2005.

${ }^{96}$ See all of this in detail: Pócs 2004.
} 
BENEDEK, Katalin

2003 Az égigérő fa (összehasonlító elemzés) [The Tree that Reached up to the Sky (A Comparative Analysis)]. In BÁLint, Péter (ed.) A meseszövés változatai. Mesemondók, mesegyüjtők és mesélők, 76-100. Debrecen: DIDAKT.

2007 A Fehérlófia meséje és párhuzamai [The Tale of Fehérlófia (Son of the White Mare) and Its Parallels]. In Hoppál, Mihály (ed.) Fehérlófia, 119129. Budapest: Európai Folklór Intézet - MTA Néprajzi Kutatóintézete L'Harmattan Kiadó.

BEnOVSKA-SĂBKovA, Milena

1992 Zmejat $v$ bălgarskija folklor [The Dragon in Bulgarian Folklore]. Sofia: Bălgarska Akademia Naukite.

Berze NAGY, János

1958 Égigérö fa. Magyar mitológiai tanulmányok [The Tree that Reached up to the Sky. Studies in Hungarian Mythology]. Pécs: Tudományos Ismeretterjesztő Társulat.

BLÉCOURT, Willem de

2012 Tales of Magic, Tales in Print: On the Genealogy of Fairy Tales and the Brothers Grimm. Manchester: Manchester University Press.

BoDGÁL, Ferenc

1960 Egy miskolci “tátos” 1741-ben [A „Tátos” in Miskolc in 1741]. Néprajzi Közlemények V(3-4):308-316.

BošKović-Stulli, Maja

1960 Kresnik-Krsnik, ein Wesen aus der kroatischen und slovenischen Volksüberlieferung [Kresnik-Krsnik, a Creature in Croatian and Slovenian Folklore]. Fabula 3:275-298.

BOYER, Régis

1986 Le monde du double. La magie chez les anciens Scandinaviens [A World of Doubles. Magic among Ancient Scandinavians]. Paris: Berg International.

BoyLe, John Andrew

1972 Turkish and Mongol Shamanism in the Middle Ages. Folklore 83:177-193.

BuRKHART, Dagmar

1967 Zum Drachenkampfthema. Motivparallelen in der südslavischen und griechischen Volksepik [On the Dragon Battle Theme. Motif Parallels in South Slavic and Greek Folk Epics]. Zeitschrift für Balkanologie V:146-159.

1968 Untersuchungen zur Stratigraphie und Chronologie der südslavischen Volksepik [Studies on the Stratigraphy and Chronology of South Slavic Folk Epics]. München: Otto Sagner. (Slavistische Beiträge 33).

1989 Kulturraum Balkan [The Balkan Culture Area]. Berlin - Hamburg: Dietrich Reimer Verlag. (Studien zur Volkskunde und Literatur Südosteuropas 5).

ČAJKANOVIĆ, Veselin

1973 Sekula se u zmiju pretvorio [Sekula Turned into a Serpent]. In Idem. Mit $i$ religija u srba, 36-45. Beograd: Srpska Književna Zadruga.

CsíKHELYI, Lenke

1984 A bolgár hősi énekek magyar vonatkozásai [Bulgarian Heroic Epics and Their Hungarian Aspects]. Ethnographia XCV:10-15. 
DÉGH, Linda

1965 Folktales of Hungary. Chicago: The University of Chicago Press.

1978 The Tree that Reached up to the Sky (Type 468). In DÉGH, Linda (ed.) Studies in East European Folk Narrative, 268-316. Bloomington: Indiana University, Folklore Institute.

DEMÉNY, István Pál

1994 A hejgetés meg a sámánének. (A Curiosa-sorozatból) [Hejgetés and the Shamanic Song (From the Curiosa Series)]. Néprajzi Látóhatár III(1-2):135150 .

1997 A magyar szóbeli hösi epika [Hungarian Oral Epic Poetry]. Csíkszereda: Pallas-akadémia Könyvkiadó.

1999a Bika képében viaskodó táltosok a régi Kínában [Táltos Battling in the Shape of Bulls in Ancient China]. In Idem. Táltosok, kerekek, lángok. Összehasonlitó folklorisztikai tanulmányok, 16-25. Csíkszereda: Pallas-Akadémia Könyvkiadó. (Curiosa 1).

1999b Párbaj kerék meg láng képében a hiedelemmondákban és a mesékben [Duel in the Shape of Wheels and Flames in Belief Legends and Folktales]. In Idem. Táltosok, kerekek, lángok. Összehasonlitó folklorisztikai tanulmányok, 38-53. Csíkszereda: Pallas-Akadémia Könyvkiadó. (Curiosa 1).

2000 Európai-e a samanizmus, keletiek-e a táltos-mondák? [Is Shamanism European? Are Táltos Legends Oriental?] In CzÉGÉNYI, Dóra - Keszeg, Vilmos (eds.) Kriza János Néprajzi Társaság Évkönyve 8, 143-163. Kolozsvár: Kriza János Néprajzi Társaság.

DiEnEs, István

1975 A honfoglaló magyarok és ősi hiedelmeik [The Conquering Hungarians and Their Ancient Beliefs]. In HaJdú, Péter (ed.) Uráli népek. Nyelvrokonaink kultúrája és hagyományai, 77-108. Budapest: Corvina Kiadó.

1981 Schamanenaristokratie in den Nomadenstaaten [Shamanic Aristocracy in Nomadic States]. In Ikola, Osmo - Kielen Seura, Suomen (Red.) Congressus Quintus Internationalis Fenno-Ugristarum (Turku, 20-27. VIII. 1980.) Pars VIII, 326-338. Turku.

DiószeGI, Vilmos

1952 A viaskodó táltosbika és a sámán állatalakú életlelke [The Battling Táltos Bull and the Shaman's Animal-Shaped Life Soul]. Ethnographia LXIII:308-355.

1953 Adatok a táltos révülésére [Data on the Trance of the Táltos]. Etnographia LXIV:303-310.

1954 A honfoglaló magyar nép hitvilága (“ősvallásunk”) kutatásának módszertani kérdései [Methodological Issues in Researching the Religion ("Ancient Religion") of the Conquering Hungarians]. Ethnographia LXV:20-65.

1958a A sámánhit emlékei a magyar népi müveltségben [The Relics of Shamanism in Hungarian Folk Culture]. Budapest: Akadémiai Kiadó.

1958b Die Überreste des Schamanismus in der ungarischen Volkskultur [The Relics of Shamanism in Hungarian Folk Culture]. Acta Ethnographica Academiae Scientiarum Hungaricae VII:97-135.

1960 Uráli párhuzamok táltosaink “felesleges csont” képzetéhez [Uralic Parallels of the Notion of the "Excess Bone" of the Táltos]. Ethnographia LXXI:455-457. 
1967 A pogány magyarok hitvilága [The Religion of Pagan Hungarians]. (Körösi Csoma Kiskönyvtár 4.) Budapest: Akadémiai Kiadó.

1969 A honfoglaló magyarok hitvilágának történeti rétegei: a világfa [The Historical Layers of the Religion of the Conquering Hungarians: The World Tree]. Népi kultúra - népi társadalom II-III:295-326.

1971a Hungarian Contribution to the Study of Shamanism. Müveltség és Hagyomány XIII-XIV:553-566.

1973 A táltos alakjának földrajzi elterjedéséhez [On the Geographic Diffusion of the Figure of the Táltos]. Szolnok Megyei Múzeumi Évkönyv I, 189-204.

Diószegi, Vilmos (ed.)

1971b Ösi magyar hitvilág. Válogatás a magyar mitológiával foglalkozó XVIII-XIX. századi müvekböl [Ancient Hungarian Religion. Selections from $18^{\text {th }}$ - and $19^{\text {th }}$-century Works on Hungarian Mythology]. Budapest: Gondolat.

DӧмӧтӧR, Ákos (comp.)

1988 A magyar tündérmesék típusai. (Magyar Népmesekatalógus 2.) [Hungarian Fairy Tale Types. (Hungarian Folktale Catalog 2)]. Budapest: MTA.

DöмÖTöR, Tekla

1982 A magyar nép hiedelemvilága [Beliefs of the Hungarians]. Budapest: Corvina Kiadó.

1983 The Hungarian female táltos. In HoppáL, Mihály (ed.) Shamanism in Eurasia, 423-430. Göttingen: Herodot.

ĐorĐEvić, Tihomir R.

1953 Veštica i vila u našem narodnom verovaniju i predanju. Vampir i druga bita $\mathrm{u}$ našem narodnom verovaniju i predanju [Witches and Fairies in Our Folk Beliefs and Tradition. The Vampire and Other Beings in Our Folk Beliefs and Tradition]. Srpski Etnografski Zbornik LXVI:5-255.

Dukova, Ute

1970 Das Bild der Drachen im bulgarischen Märchen [The Image of the Dragon in Bulgarian Folktales]. Fabula 11:209-252.

ERDŐDI, József

1937 Huj, huj, hajrá! Szegedi Füzetek II:228-233.

FERENCZI, Imre

1974 A táltos és garabonciás képzete a jugoszláviai magyaroknál [The Notion of the Táltos and the Garabonciás among Hungarians in Yugoslavia]. Ehnographia LXXXV:262-275.

FODOR, István

1973 Honfoglaláskori müvészetünk iráni kapcsolatainak kérdéséhez. A sóshartyáni korongpár [On the Iranian Connections of Our Conquest-era Art. Two Discs from Sóshartyán]. Archeológiai Értesitö 100.32-40.

2003 Über die vorchristliche Religion der Altungarn [On the Pre-Christian Religion of Ancient Hungary]. Acta Ethnographica Hungarica 48:327-351.

2004 A magyarok ösi vallásáról. (Vallástudományi Tanulmányok 6.) [On the Ancient Religion of the Hungarians. (Studies on Religion 6.)] Budapest: Magyar Vallástudományi Társaság. 
2005 Az ösi magyar vallásról [On the Ancient Hungarian Religion]. In JANKovics, Marcell - MolnáR, Ádám (eds.) Csodaszarvas I. Östörténet, vallás, hagyomány, 11-34. Budapest: Molnár Kiadó.

2012 A sas szerepe honfoglalóink hitvilágában [The Role of the Eagle in the Religion of the Conquering Hungarians]. In MolnáR, Ádám (ed.) Csodaszarvas. Östörténet, vallás és néphagyomány IV, 21-47. Budapest: Molnár Kiadó.

GeorgIeva, Ivanička

1983 Bălgarska narodna mitologija [Bulgarian Folk Mythology]. Sofia: Nauka i izkustvo.

GinZBuRg, Carlo

1966 I Benandanti. Stregoneria e culti agrari tra Cinquecento e Seicento [The Benandanti. Witchcraft and Agrarian Cults in the Sixteenth and Seventeenth Centuries]. Torino: Einaudi.

2003 Éjszakai történet. A boszorkányszombat megfejtése. [A Night Story. Deciphering the Witches' Sabbath]. Budapest: Európa Könyvkiadó. [Storia notturna. Una decifrazione del sabba. Torino: Einaudi, 1989.]

Gombocz, Zoltán

1960 Honfoglalás elötti bolgár-török jövevényszavaink. [Pre-Conquest-Era Bulgaro-Turkic Loanwords]. Budapest: Akadémiai Kiadó. (Nyelvtudományi Értekezések 24).

Gunda, Béla

1963 Totemistische Spuren in der ungarischen Táltos-Überlieferung [Totemistic Traces in Hungarian Táltos Traditions]. In Diószegi, Vilmos (ed.) Glaubenswelt und Folklore der sibirischen Völker, 45-56. Budapest: Akadémiai Kiadó.

GYÖRFFY, György

1977 Honfoglalás, megtelepedés és kalandozások [Conquest, Settlement and Exploits]. In BARTHA, Antal - CZEGLÉDY, Kártoly - RóNA-TAS, András (eds.) Magyar östörténeti tanulmányok, 123-156. Budapest: Akadémiai Kiadó.

HERTZ, Wilhelm

1862 Der Werwolf. Beitrag zur Sagengeschichte [The Werewolf. A Contribution to the History of the Legend]. Stuttgart: Kröner.

HoLm, Nils G. (ed.)

1982 Religious Ecstasy. Based on Papers read at the Symposium on Religious Ecstasy held at Abo, Finland, on the 26th-28th of August, 1982. Stockholm: Almqvist and Wiksell International. (Scripta Instituti Donneriani Åboensis $\mathrm{XI})$.

HoppáL, Mihály

$1975 \mathrm{Az}$ uráli népek hiedelemvilága és a samanizmus [The Beliefs and Shamanism of Uralic Peoples]. In HAJdú, Péter (ed.) Uráli népek. Nyelvrokonaink kultúrája és hagyományai, 211-233. Budapest: Corvina Kiadó.

1981 A Toldi mitológiai háttere [The Mythological Background of the Toldi Legend]. Új írás 21(11):68-101.

1984 Traces of Shamanism in Hungarian Folk Beliefs. In HoppáL, Mihály (ed.) Shamanism in Eurasia 2. 430-449. Göttingen: Herodot. [In SIIKALA - HoppáL: Studies on Shamanism, Finnish Anthropological Society, 156-175. Helsinki Budapest: Akadémiai Kiadó. 1992.] 
1988 Finnugor mitológia [Finno-Ugric Mythology]. In ToKarev, S. A. (EIC): Mitológiai enciklopédia I. 530-538. Budapest: Gondolat Kiadó. [Moscow 1980-1982.]

1996 A magyar samanizmus és a honfoglalók hitvilága [Hungarian Shamanism and the Religion of the Conquering Hungarians]. In Pócs, Éva - VoIGT, Vilmos (eds.) Ösök, táltosok, szentek. Tanulmányok a honfoglaláskor és Árpád-kor folklórjából, 67-76. Budapest: MTA Néprajzi Kutatóintézete.

1998 Az ösi magyar hitvilágról [On the Ancient Hungarian Religion]. In VoIGT, Vilmos - BALÁzs, Géza (eds.) A magyar jelrendszerek évszázadai, 23-33. Budapest: Magyar Szemiotikai Társaság.

2001 Cosmic Symbolism of Siberian Shamanhood. In PentikäInen, Juha (ed.) Religion and Nature in Asian Cultures, 75-87. Cambridge: Harvard Press.

IPOLYI, Arnold

1854 Magyar mythologia [Hungarian Mythology]. Pest: Heckenast Gusztáv. JAKOBSON, Roman - RuŽIČIĆ, Gojko

1950 The Serbian Zmaj Ognjeni Vuk and the Russian Vseslav Epos. Bruxelles: Institut de Philologie et d'Histoire Orientales et Slaves.

JOHANSEN, Ulla

2006 Gondolatok a régi török és mongol samanizmusról [Thoughts on Old Turkic and Mongolian Shamanism]. In JANKovics, Marcell - MolnáR, Ádám (eds.) Csodaszarvas II. Östörténet, vallás, hagyomány, 139-156. Budapest: Molnár Kiadó.

Jung, Károly (pub.)

1990 Délszláv hösénekek Székely Jánosról (Fordította és a bevezetést írta: Borislav Jankulov) [South Slavic Heroic Epics about János Székely (Translated and introduction by Borislav Jankulov)]. Újvidék: Forum Könyvkiadó.

KÁLMÁNY Lajos

1917 Összeférhetetlen tátosainkról [On Our Belligerent Tátos]. Ethnographia XXVIII:260-266.

Kalojanov, Ančo

1995 Bălgarskoto šamanstvo [Bulgarian Shamanism]. Sofia: ROD.

KaRJalainen, Kustaa Fredrik

1927 Religion der Jugra Völker III. [The Religion of Ugric Peoples III]. Helsinki: Suomalainen Tiedeakatemia. (Folklore Fellows' Communications 63).

KARLINGER, Felix - TURCZYNSKI, Emanuel (eds.)

1982 Rumänische Sagen und Sagen aus Rumänien [Romanian Legends and Legends from Romania]. Berlin: Erich Schmidt Verlag. (Rumänische Volkskunde II.)

Katona, Lajos

1907 Túlvilági látomások kódexeinkben [Otherworldly Visions in Our Codices]. Akadémiai Értesitó 500-507.

KeLEMINA, Jakob

1930 Bajke in pripovedke slovenskego ljudstva z mitološkim uvodom [Fairy Tales and Stories of the Slovenian People with a Mythological Introduction]. Celje: Moholjeva Druzba. 
Kenin-Lopsan, Mongus Borakovic

2003 A tuva sámánok mágiája (ford. Kovács Zoltán) [The Magic of Tuvan Shamans (Trans. Zoltán Kovács]. In Molnár, Ádám (ed.) A sámánhit emlékei. Török népek, 213-246. Budapest: Balassi Kiadó.

KLANiCZAY, Gábor

1983 Benandante - kresnik - zduhač - táltos. Samanizmus és boszorkányhit érintkezési pontjai Közép-Európában [Benandante - Kresnik - Zduhač - Táltos. Contact Points of Shamanism and Witchcraft in Central Europe]. Ethnographia XCIV:116-134.

KLAPPER, Joseph

1910 Vampir, Werwolf, Hexe. Mitteilungen aus Handschriften [Vampires, Werewolves, Witches. Messages from Manuscripts]. Mitteilungen der Schlesischen Gesellschaft für Volkskunde XII:180-185.

KodOLÁnYI, János

1945 A táltos a magyar néphagyományban [The Táltos in Hungarian Folk Kovács, Ágnes Traditions]. Ethnographia LVI:31-37.

1984 Az égig érő fa meséjének redakciói és samanisztikus motívumaik [Redactions and Shamanistic Motifs of the Tale of the Tree that Reached up to the Sky]. Ethnographia XCV:16-31.

Krauss, Friedrich S.

1908 Slavische Volksforschungen: Abhandlungen über Glauben, Gewohnheitrechte, Sitten, Bräuche und die Guslarenlieder der Südslawen [Slavic Folklore Research: Treatises on Beliefs, Customary Rights, Customs and Traditions, and the Guslar Epics of the South Slavs]. Leipzig: Wilhelm Heims.

KSENOFONTOv, Gavril Vasiljevic

2003 Jakut sámán legendák és elbeszélések (ford. Kovács Zoltán) [Yakut Shaman Legends and Narratives (Trans. Zolán Kovács)]. In MolNár, Ádám (ed.) A sámánhit emlékei. Török népek, 247-283. Budapest: Balassi Kiadó.

LÁszLó, Gyula

1959 A magyar táltos alakjáról. Jegyzetek Diószegi Vilmos: A sámánhit emlékei a magyar népi müveltségben (Budapest, 1958. Akadémiai Kiadó, 472 o.) címü könyvéhez [On the Figure of the Hungarian Táltos. Notes on Vilmos Diószegi's book, Relics of Shamanism in Hungarian Folk Culture (Budapest, 1958: Akadémiai Kiadó, 472 p.)]. Ethnographia LXX:446-449.

1990 Különvélemény ösvallásunkról [A Dissenting Opinion on Our Ancient Religion]. In Idem: Öseinkröl, 158-171. Budapest: Gondolat Kiadó.

LeHOCZKY, Tivadar

1887 Beregmegyei boszorkány-perek [Witch Trials in Bereg County]. Hazánk, Történelmi Közlöny VII:296-306.

LILEK, Emilian

1900 Familien und Volksleben in Bosnia und in der Hercegowinen [Family-life and Folklife in Bosnia and Hercegovina]. Zeitschrift für Österreichische Volkskunde VI:23-30, 53-72, 164-172, 202-225.

LORD, Albert B.

1971 Some Common Themes in the Balkan Slavic Epic. Congrès international 
des études balkaniques et sud-est européennes I., Sofia 1966, VII: Litérature, ethnographie, folklore, 653-681. Sofia: Éditions de l'Académie Bulgare des Sciences.

1986 Narrative Themes in Bulgarian Oral-Traditional Epic and Their Medieval Roots. Byzantino-bulgarica VIII:102-111.

MACDERMOT, Violet

1971 The Cult of the Seer in the Ancient Middle East. A contribution to current research on hallucinations drawn from Coptic and other texts. London: Wellcome Institute of the History of Medicine.

MagYAR, Zoltán

1998 Szent László alakja a gyimesi csángók szájhagyományában [The Figure of St. László in the Oral Lore of the Gyimes Csángós]. In Pozsony, Ferenc (ed.) Kriza János Néprajzi Társaság Évkönyve 6, 190-218. Kolozsvár: Kriza János Néprajzi Társaság.

MARINOV, Dimităr

1914 Narodna vjara i religiozni narodni običai [Folk Religion and Religious Folk Customs]. Sbornik za narodni umotvorenija i narodopis XVIII.

Mesterházy, Károly

1978 Hitvilág és társadalom kapcsolata a honfoglaló magyarságnál [The Relationship between Religion and Society among the Conquering Hungarians]. In HoppáL, Mihály - Istvánovits, Márton (eds.) Mítosz és történelem, 39-47. Budapest: MTA Néprajzi Kutatócsoport. (Előmunkálatok a Magyarság Néprajzához 3)

1994 Többgyökerü ösi vallásunk emlékei [The Remnants of Our Multi-rooted Ancient Religion]. In Kovács, László (ed.) Honfoglalás és régészet, 301-308. Budapest: Balassi Kiadó. (A honfoglalásról sok szemmel I).

MÉszÖLY, Gedeon

1952 Az ugorkori sámánosság magyar szókincsbeli emlékei [Vestiges of Ugric-era Shamanism in the Hungarian Vocabulary]. Magyar Nyelv 48:46-61.

MiKac, Jakov

1934 Vjerovanja (Brest u Istri) [Beliefs (Brest in Istria)]. Zbornik za narodni život $i$ običaje južnih slavena XXIX:195-199.

MoszYŃsKI, Kazimierz

1967 Kultura łudowa słowian II. Kultura duchowa I. [Slavic Culture II. Spiritual Culture]. Warsaw: Książka i Wiedza. [Kraków, 1929.]

Multedo, Roccu

1982 Le folklore magique de la Corse [The Magic Folklore of Corsica]. Nice: Belisane.

MuşleA, Ion - BîrleA, Ovidiu

1970 Tipologia folclorului din raspunsurile la chestionarele lui B.P. Hasdeu [Folklore Typology Based on Responses to a Questionnaire by B.P. Hasdeu]. Bucureşti: Minerva.

Oosten, Jarich G.

1985 The War of the Gods. The Social Code of Indo-European Mythology. London - Boston - Melbourne - Henley: Routledge \& Kegan Paul. 
PAASONEN, Heikki

1909-1910 Über die ursprüngliche Seelenvorstellungen bei den finnisch-ugrischen Völker [On the Ancient Notions of the Soul among Finno-Ugric Peoples]. PAIS, Dezső Journal de la Société Finno-Ougrienne 26:1-27.

1975a Reg [1.] A régi magyarság szellemi életének kérdésköréből. Reg [2.] [On the Spiritual Life of the Ancient Hungarians]. In Idem. A magyar ösvallás nyelvi emlékeiből, 15-33, 109-142. Budapest: Akadémiai Kiadó. [1948, 1958.]

1975b Huj - huj - kaját. Hangutánzó-hangkifejező szavaink néhány ősi rokonságban levő csoportjáról [Huj - Huj - Kaját. On the Ancient Relations of Some of Our Onomatopoeic Words]. In Idem. A magyar ösvallás nyelvi emlékeiböl, 42-72. Budapest: Akadémiai Kiadó. [1957.]

1975c A táltos meg az orvos [The Táltos and the Doctor]. In Idem. A magyar ösvallás nyelvi emlékeiböl, 73-87. Budapest: Akadémiai Kiadó. [1958.]

1975d A finnugorság lélekképzetei és rájuk vonatkozó kifejezései [Notions of the Soul and Associated Expressions among Finno-Ugric Peoples]. In Idem. $A$ magyar ősvallás nyelvi emlékeiből, 185-209. Budapest: Akadémiai Kiadó. [1958.]

PAKSA, Katalin

1999 Magyar Népzenetörténet [The History of Hungarian Folk Music]. Budapest: Balassi Kiadó.

PAMFILE, Tudor

1916 Mitologie româneascâ I. Dusmani si prieteni ai omului [Romanian Mythology

I. Enemies and Friends of Man]. Bucureşti: Librăriile Socec \& Co.

PAULSON, Ivar

1958 Die primitiven Seelenvorstellungen der nordeurasischen Völker. Eine religionsethnographische und religionsphänomenologische Untersuchung [The Primitive Notions of the Soul among Northern Eurasian Peoples. A Religio-Ethnographic and Religio-Phenomenological Study]. Stockholm: Statens Etnografiska Museum. (Monograph Series 5).

Pedrosa, José Manuel

2000 Entre la magia y la religión: Oraciones, conjuros, ensalmos [Between Magic and Religion: Prayers, Spells, Incantations]. Oiartzun: Sendoa Editorial. (Biblioteca Mitica 2).

Petrović, Sreten

1999 Srpska mitologija [Serbian Mythology]. Niš: Izdavač Prosveta.

PeUCKert, Will-Erich

1960a Der Zweite Leib [The Second Body]. In Idem. Verborgenes Niedersachsen. Untersuchungen zur niedersächsischen Volkssage und zum Volksbrauch, 1135. Göttingen: O. Schwartz.

1960b Die Walriderske im Siebrand [The Walriderske in the Sieve]. In Idem. Verborgenes Niedersachsen. Untersuchungen zur niedersächsischen Volkssage und zum Volksbrauch, 91-102. Göttingen: O. Schwartz. 
Pócs, Éva

1988 Sárkányok, ördögök és szövetségeseik a délszláv-magyar kapcsolatok tükrében [Dragons, Devils and Their Allies in Light of South Slav-Hungarian Relations]. Folklór és Tradíció VI. 145-170.

1989a Fairies and Witches on the Boundary of South-Eastern and Central Europe. Helsinki: Academia Scientiarum Fennica. (Folklore Fellows' Communications 243).

1989b Hungarian Táltos and his European Parallels. In Hoppál, Mihály - Pentikäinen, Juha (eds.): Uralic Mythology and Folklore. (Ethnologia Uralica 1.) 251-276. Budapest - Helsinki: Ethnographic Institute of the Hungarian Academy of Sciences - Finnish Literature Society.

1994 A kígyó, a mennykő és a tehenek. "Kettős samanizmus" és boszorkányság Közép-DK-Európában [The Serpent, the Thunderbolt, and the Cows. „Dual Shamanism" and Witcheraft in Central and Southeastern Europe]. Folklór és tradíció 7:89-102.

1995 Traces of Indo-European Shamanism in South-East Europe. In KoIva, Mare - Vassiljevna, Kai (eds.) Folk belief today, 313-320. Tartu: Institute of the Estonian Language and Estonian Museum of Literature.

1996 Magyar samanizmus a kora újkori forrásokban [Hungarian Shamanism in Early Modern Sources]. In Pócs, Éva - Voigt, Vilmos (eds.) Ösök, táltosok, szentek. Tanulmányok a honfoglaláskor és Árpád-kor folklórjából, 83-128. Budapest: MTA Néprajzi Kutatóintézete.

1998 Transz és látomás Európa népi kultúráiban [Trance and Vision in the Folk Cultures of Europe]. In Idem (ed.) Eksztázis, álom, látomás. Vallásetnológiai fogalmak tudományközi megközelitésben, 15-55. Budapest - Pécs: Balassi Kiadó - University Press. (Tanulmányok a transzcendensröl I).

1999 Between the Living and the Dead. A Perspective on Witches and Seers in the Early Modern Age. (Translated by Szilvia Rédey and Michael Webb). Budapest - New York: Central European University Press.

2002 Natura és kultúra - halál vagy élet? Kettős lények és "emberré avatás" [Nature and Culture-Death or Life? Double beings and the "Rite of Passage of Becoming Human"]. In Idem (ed.) Mikrokozmosz, makrokozmosz. Vallásetnológiai fogalmak tudományközi megközelitésben, 165-220. Budapest: Balassi Kiadó. (Tanulmányok a transzcendensröl III).

2004 Néhány új szempont a regölés és a regösének kutatásához [New Considerations for the Research of Regölés and the Regösének (Regös Song)]. In Andrásfalvy, Bertalan - Domokos, Mária - NaGY, Ilona (eds.) $A z$ Idö rostájában. Tanulmányok Vargyas Lajos 90. születésnapjára II, 285-333. Budapest: L'Harmattan.

2010 Álommedicina. A gyógyítás és rontás éjszakai világa [Dream Medicine. The Night World of Healing and Hexing]. In Pócs, Éva (ed.) Mágikus és szakrális medicina. Vallásetnológiai fogalmak tudományközi megközelítésben, 428458. Budapest: Balassi Kiadó. (Tanulmányok a transzcendensröl VII).

2012a Hiedelemszövegek [Belief Narratives]. Budapest: Balassi Kiadó. (A magyar folklór szövegvilága 1). 
2012b Átmeneti rítusok a halál után [Transition Rites After Death]. In LANDGRAF, Ildikó - NAGY, Zoltán (eds.) Az elkerülhetetlen. Vallásantropológiai tanulmányok Vargyas Gábor tiszteletére, 763-792. Budapest: PTE Néprajz - Kulturális Antropológia Tanszék - MTA BTK Néprajztudományi Intézet L'Harmattan Kiadó - Könyvpont Kiadó.

2014 Kommunikáció a tündérekkel Délkelet-Európában [Communicating with Fairies in Southeastern Europe]. In VASSÁNYI, Milós - SePSI, Enikő - VoIgT, Vilmos (eds.) A spirituális közvetítő, 143-163. Budapest: Károli Gáspár Református Egyetem - L'Harmattan Kiadó.

2017 Shamanism or Witchcraft? The Táltos before the Tribunals. In KLAniczaY, Gábor - Pócs, Éva (eds.) Witchcraft and Demonology in Hungary and Transylvania, 221-289. London: Palgrave Macmillan. (Palgrave Historical Studies in Witchcraft and Magic).

2019 [forthcoming]. Látók, tündérek, táltosok. A természetfeletti kommunikáció Közép-Kelet-Európában [Seers, Fairies, Táltos. Supernatural Communication in South-Central Europe]. Budapest: Balassi Kiadó.

POLNER, Zoltán

2011 Csillagok tornácán. Táltosok, boszorkányok, hetvenkedők [On the Porch of the Stars. Táltos, Witches, Braggarts]. Szeged: Bába és Társai Kiadó. (A Tisza hangja 110).

Pozsony, Ferenc

2005 Samanizmus és medvekultusz Moldvában? [Shamanism and Bear Cult in Moldavia?] In JANKovics, Marcell - Molnár, Ádám (eds.) Csodaszarvas I. Östörténet, vallás, hagyomány, 157-172. Budapest: Molnár Kiadó.

PuCHNER, Walter

1977 Brauchtumserscheinungen im griechischen Jahreslauf und ihre Beziehungen zum Volkstheater: theaterwissenschaftlich-volkskundliche Querschnittstudien zu südbalkan-mediterranen Volkskultur [Traditional Phenomena in Greek Life and Their Relation to Folk Theater: Theatrological-Ethnographic Cross-sectional Studies of South Balkan and Mediterranean Folk Culture]. Wien: Selbstverlag des Österreichischen Museums für Volkskunde. (Veröffentlichungen des Österreichischen Museums för Volkskunde XVIII).

2007 Studien zur Volkskunde Süd-Ost-Europes und des mediterranen Raums [Studies on Southeast Europe and the Mediterranean]. Wien: Böhlau.

RóHEIM, Géza

1920 Lucaszék [St. Lucy’s Stool]. In Idem. Adalékok a magyar néphithez II, 29227. Budapest: Hornyánszky Viktor.

1925 Magyar néphit és népszokások [Hungarian Folk Beliefs and Folk Customs]. Budapest: Athenaeum Kiadó.

1984 A magyar samanizmus [Hungarian Shamanism]. In Idem. Primitív kultúrák pszichoanalitikus vizsgálata, 171-228. Budapest: Gondolat Kiadó. [Hungarian Shamanism. In Psychoanalysis and the Social Sciences III, 131-169. New York: International Universities Press. 1961.]

Schmaus, Alois

1969 Volksmythologie und Heldenepik [Folk Mythology and Heroic Epics]. In Foltin, H. F. -Greverus, I.-M. - Schwebe, J. (eds.) Probleme der Volks-, 
Kultur- und Sozialforschung. Festschrift für Gerhard Heilfurth zum 60. Geburtstag, 121-128. Göttingen: Schwartz.

ScHMIDT, Leopold

1952 Der "Herr der Tiere" in einigen Sagenlandschaften Europas und Eurasias [The "Lord of the Animals" in the Mythical Landscapes of Europe and Eurasia]. Anthropos XLVI:509-538.

SCHNEEWEISS, Edmund

1961 Volksglaube und Volksbrauch [Folk Belief and Folk Customs]. Berlin: Walter de Gruyter. Serbo-kroatische Volkskunde I.

SCHRAM, Ferenc

1970 Magyarországi boszorkányperek, 1526-1768 II. [Witch Trials in Hungary, 1526-1768 II.]. Budapest: Akadémiai Kiadó.

SEBESTYÉN, Gyula

1900 A magyar varázsdob [The Hungarian Magic Drum]. Ethnographia XI:433446.

1902 Regös-énekek [Regös Songs)]. (Magyar Népköltési Gyüjtemény. Új folyam ŠEŠO, Luka IV.) Budapest: Athenaeum Kiadó.

2000/2003 O krsniki. Od tradicijske pojave u predajana do stvarnog iscjelitela [On the Krsniks. From His Traditional Appearance in Legends to an Actual Healer]. Studia ethnologica Croatica 14/15:23-53.

ŠMITEK, Zmago

2003 Šamanizem na Slovenskem? Dileme o pojmih in pojavih šamanizme, obsedenosti in ekstaze. [Shamanism in Slovenia? Dilemmas of the Concepts and Phenomena of Shamanism, Possession, and Ecstasy]. Studia Mythologica Slavica VI:149-162.

Solymossy, Sándor

1922 Keleti elemek népmeséinkben [Oriental Elements in Our Folktales]. Ethnographia XXXIII:30-44.

1929 Magyar ösvallási elemek népmeséinkben [Elements of the Ancient Hungarian Religion in Our Folktales]. Ethnographia XL:133-152.

1930 Az égbenyúló fáról szóló mesei motívumok [Tale Motifs of the Tree that Reached up to the Sky]. Ethnographia XLI:61-62.

1931 Népmeséink sárkányalakja [The Dragon in Our Folktales]. Ethnographia XLII:113-132.

1937 A magyar ősi hitvilág [Ancient Hungarian Religion]. In VISKI, Károly (ed.) $A$ Magyarság Néprajza IV. A Magyarság szellemi néprajza, 340-382. Budapest: Királyi Magyar Egyetemi Nyomda.

SOMFAI KARA, Dávid

2007 A Fehérlófia Eurázsia szerte [Fehérlófia (Son of the White Mare) Throughout Eurasia]. In Hoppél Mihály (ed.): Fehérlófia, 111-118. Budapest: Európai Folklór Intézet - MTA Néprajzi Kutatóintézete - L’Harmattan Kiadó.

STADTMÜLLER, Georg

1954 Altheidnischer Volksglaube und Christianisierung in Albanien [Old Pagan Folk Beliefs and Christianization in Albania]. Orientalia Christiana periodica $\mathrm{XX}: 211-246$. 
Stojanovič-LAFAZANOvSKa, Lidija

1996 Tanatološkiot prazvor na životot. Fenomenot žrtvuvanje vo makedonskata narodna knizevnost. / The Thanatological Archetype of Life. The Phenomenon of Sacrificing in the Macedonian oral literature. Skopje: Institut za folklor "Marko Cepenkov".

SZENDREY, Ákos

1946 A magyar lélekhit [Hungarian Spirituality]. Ethnographia LVII:34-46.

1956 Babvetés [Divination from Beans]. Néprajzi Értesitö XXXVIII:119-128.

Togan, A. Zeki Validi

1939 Ibn Fadlān's Reisebericht von A. Zeki Validi Togan [Ibn Fadlān's Travelogue by A. Zeki Validi Togan]. Leipzig: Deutsche Morgenländische Gesellschaft. (Abhandlungen für die Kunde des Morgenlandes XXIV/I).

Tolley, Clive

2008 Shamanism in Norse Myth and Magic 1-2. Helsinki: Academia Scientiarum Fennica. (Folklore Fellows' Communications 296).

Tolstoj, N. I. - TOLSTAJA, S. M.

1981 Zametki po slavjanskomu jazyčestvu 5. Zaščita ot grada v Dragačeve i drugih serbskih zonah [Slavic Linguistic Commentaries 5: Fending Off Hail in Dragačev and Other Serbian Regions]. In Vinogradova, L. I. - SMIRNov, Ju.

То́тн G., Péter

I. (eds.) Slavjanskij i Balkanskij folklore, 44-120. Moskva: Izdatelstvo Nauka.

2001 Folyampróba - liturgikus vízpróba - boszorkányfürösztés. Istenítéleti eljárások a boszorkányperekben [River Tests, Liturgical Water Tests, Witch Bathings. Trials by Ordeal in Witch Trials]. In Pócs, Éva (ed.) Demonológia és boszorkányság Európában, 249-292. Budapest - Pécs: L'Harmattan - PTE Néprajz Tanszék. (Studia Ethnologica Hungarica I).

VAJDA, László

1959 Zur phaseologischen Stellung des Schamanismus [On the Phaseological Position of Shamanism]. Ural-Altaische Jahrbücher 31:456-485.

VAKARELSKI, Hristo

1969 Bulgarische Volkskunde [Bulgarian Folklore]. Berlin: De Gruyter.

VARGYAS, Gábor

1997 A "magyarok totemizmusa" nyomában [Tracing "Hungarian Totemism"]. In Kovács, László - PALÁdi-Kovács, Attila (eds.) Honfoglalás és néprajz, 323331. Budapest: Balassi Kiadó. (A honfoglalásról sok szemmel IV).

VARGYAS, Lajos

1977 Honfoglalás előtti keleti elemek a magyar folklórban [Pre-Conquest Oriental Elements in Hungarian Folklore]. Történelmi Szemle 19(1):107-121.

1978 A honfoglaló magyarság hitvilágának legfejlettebb rétege a nyelv és a folklór tükrében [The Most Developed Layer of Conquest-era Hungarian Religion in Language and Folklore]. In HoppáL, Mihály - Istvánovits, Márton (eds.) Mítosz és történelem, 15-28. Budapest: MTA Néprajzi Kutató Csoport. (Elömunkálatok a Magyarság Néprajzához 3).

1979 A regösének problémájának újabb, zenei megközelítése [A New, Musical Approach to the Regös Song]. Ethnographia XC:163-190. 
1985 Magyarság a folklórban és az időben [Hungarians in Folklore and in Time]. In Szombathy, Viktor (ed.) Az öshazától a Kárpátokig, 108-159. Budapest: Panoráma Kiadó.

1988 A hösének maradványai népköltészetünkben [Vestiges of Heroic Epics in Our Folk Poetry]. In VARGYAs, Lajos (EIC): Magyar Néprajz V. Népköltészet, 398413. Budapest: Akadémiai Kiadó.

VERBICKIJ, Vasilij Ivanovic

2003 Az altaji török sámánszertartás (ford. Kovács Zoltán) [The Altaic Turkic Shamanic Ritual (Trans. Zolán Kovács)]. In Molnár, Ádám (ed.) A sámánhit emlékei. Török népek, 159-212. Budapest: Balassi Kiadó.

Voigt, Vilmos

1997-1998 A magyar ősvallás kérdése I-II. [The Issue of Ancient Hungarian Religion I-II.] Ethnographia CVIII:365-418; CIX. 71-96.

1998 Hösepika [Heroic Epics]. In VoIgt, Vilmos (ed.) A magyar folklore, 149-183. Budapest: Osiris.

2006 A vallás megnyilvánulásai. Bevezetés a vallástudományba [The Manifestations of Religion. An Introduction to Religious Studies]. Budapest: Timp Kiadó.

2012 A magyar samanizmusról - röviden [On Hungarian Shamanism - Briefly]. In Molnár, Ádám (ed.) Csodaszarvas IV. Östörténet, vallás és néphagyomány, 85-98. Budapest: Molnár Kiadó.

VRAŽINOVSKI, Tanas

1995 Narodna demonologija na makedoncite [The Folk Demonology of the Macedonians]. Skopje-Prilep: Institut za staroslovenska kultura.

ZEČEvIĆ, Slobodan

1969 Zmaj u narodnom verovanju severistočne Srbije [The Dragon in the Folk Beliefs of Northeastern Serbia]. Makedonski Folklor II:361-368.

1981 Mitska biča srpskih predanja [Mythical Creatures in Serbian Tradition]. Beograd: "Vuk Karadžićc" Etnografski Muzei.

Archival sources used:

Garabonciás, Birth, Táltos, and Wizard groups of the Archives of Hungarian Folk Beliefs (at the Institute of Ethnology of HAS, Research Centre for the Humanities). 
Éva Pócs is Professor Emeritus at the University of Pécs, Hungary, and Principal Investigator of the ERC project Vernacular religion on the boundary of Eastern and Western Christianity: continuity, changes and interactions. The crucial areas of her research are: general concepts of religious anthropology (such as the cult of the dead, divination, supernatural communication, witchcraft, fairy cult, shamanism); the comprehensive analysis of modern folk religion and folk beliefs; witchcraft and demonology in the early modern period; religious folklore, incantations. She is the series editor of conference volumes and sourcebooks on early modern religion, and the editor or co-editor of 28 volumes on religious anthropology and folklore, including Witchcraft and Demonology in Hungary and Transylvania. (Palgrave Historical Studies in Witchcraft and Magic, ed. with Gábor Klaniczay), London, 2017. She has written 11 books, including Fairies and Witches at the Boundary of South-Eastern and Central Europe (Helsinki, 1989) and Between the Living and the Dead: A Perspective on Witches and Seers in the Early Modern Age (Budapest, 1998). Email: pocse@chello.hu 